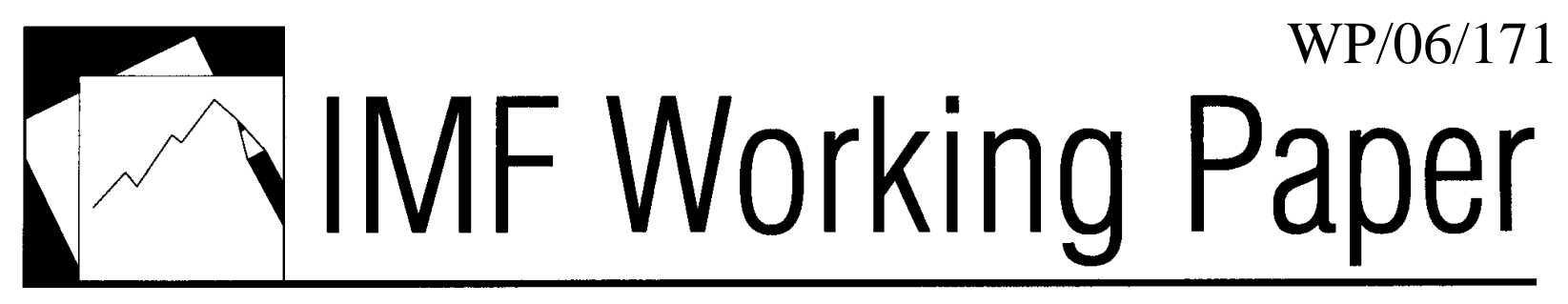

\title{
Weathering the Storm So Far: The Impact of the 2003-05 Oil Shock on Low-Income Countries
}

Paolo Dudine, James John, Mark Lewis, Luzmaria Monasi, Helaway Tadesse, Joerg Zeuner 



\title{
IMF Working Paper
}

Policy Development and Review Department

Weathering the Storm So Far:

The Impact of the 2003-05 Oil Shock on Low-Income Countries

\author{
Prepared by Paolo Dudine, James John, Mark Lewis, Luzmaria Monasi, \\ Helaway Tadesse, Joerg Zeuner ${ }^{1}$
}

Authorized for distribution by Patricia Alonso-Gamo

July 2006

\begin{abstract}
This Working Paper should not be reported as representing the views of the IMF.

The views expressed in this Working Paper are those of the author(s) and do not necessarily represent those of the IMF or IMF policy. Working Papers describe research in progress by the author(s) and are published to elicit comments and to further debate.

This paper examines the impact of the 2003-05 oil price increase on the balance of payments positions and IMF financing needs of low-income country oil importers. It finds that stronger exports reflecting favorable global conditions, a compression of oil import volumes due to the pass-through of world prices to domestic consumers, and a large increase in capital inflows helped low-income countries cope with the oil price shock. Preliminary data suggest that reductions in oil import volumes have not harmed growth. While fiscal balances generally improved, quasi-fiscal liabilities may be building. Lower demand for IMF assistance may reflect broader trends, but further oil price increases could put pressure on additional countries in 2006 and beyond.

JEL Classification Numbers: E62, F32, H2, H62, O13, Q43

Keywords: oil, oil shock, balance of payments, adjustment, fiscal, quasi-fiscal, pass-through, low-income country, IMF financing

Author(s) E-Mail Address: pdudine@imf.org, jjohn@imf.org, mlewis@imf.org, lmonasi@imf.org, htadesse@imf.org, jzeuner@imf.org

\footnotetext{
${ }^{1}$ The authors are all members of the PRGF Operations Division in the Policy Development and Review Department. They are grateful for helpful comments from Patricia Alonso-Gamo, Thomas Dorsey, Matthew Fisher, Sanjeev Gupta, Adnan Mazarei, and Mark Plant, as well as colleagues in the Policy Development and Review, African, Fiscal Affairs, and Research Departments of the IMF. Any errors are the responsibility of the authors.
} 


\section{Contents}

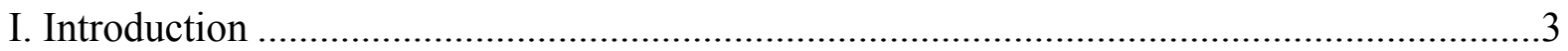

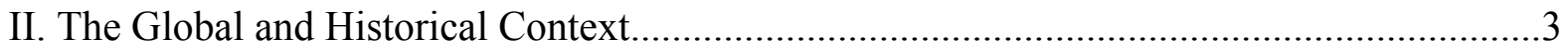

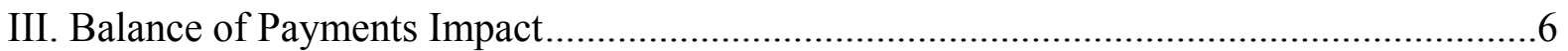

A. Average Impact of the Oil Shock.................................................................. 6

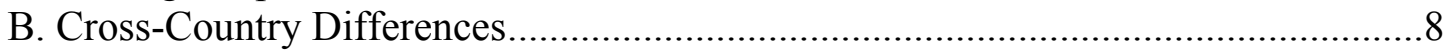

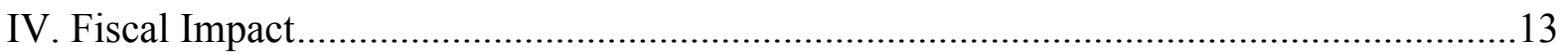

V. Looking Forward—Possible Vulnerabilities .............................................................19

VI. Conclusions and Implications for Demand for IMF Resources ................................20

Appendix I-Comparison to Oil Shocks of the 1970s .....................................................26

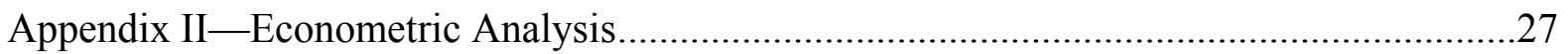




\section{INTRODUCTION}

A puzzling feature of the large increase in world oil prices since 2002 is the seemingly limited macroeconomic impact on low-income countries (LICs). The balance of payments and fiscal positions in these countries - expressed relative to GDP - have on average improved in 2003-05. And while development needs in LICs remain vast, balance of payments financing needs, as demonstrated by demand for IMF resources, have declined over this period (Figure 1), and there has not yet been a request for support under the newlycreated Exogenous Shocks Facility.

This paper examines the effects of the oil shock on LICs, factors that mitigated its impact, and steps taken by countries to adjust to the shock. The focus of the analysis is on balance of payments and fiscal positions. The paper assesses the impact of the oil shock on the 66 oil importers among the 78 Poverty Reduction and Growth Facility (PRGF)-eligible countries, and compares results for 2005 to 2003 . $^{2}$

The structure of the paper is as follows. The role of global conditions is discussed in Section II. Section III examines the balance of payments impact of the current shock, looking at different components of the current and capital accounts as well as trends in reserves. Econometric evidence on the determinants of two important aspects of country adjustmentchanges in oil import volumes and external borrowing - is also presented. Section IV discusses the impact of the oil shock on fiscal balances. Section V considers how further price increases may affect LICs going forward, and Section VI concludes, considering why the demand for Fund resources has not been greater.

\section{The Global and Historical Context}

The global environment was significantly more favorable in 2003-05 than it had been during previous oil shocks. This helps explain why high prices have had less impact than might have been expected. As shown in Text Table 1 below, global output and trade growth have been much higher, and interest rates much lower, when compared to earlier periods.

While nominal oil prices reached new highs in 2005, real prices have remained below the 1980 peak and the increase over 2003-05 occurred relatively gradually, allowing countries more time to adjust. The measured pace of annual oil price increases in recent years seems consistent with demand-side pressures from global growth, in contrast to the sharp supplyside shocks of the 1970s (Figure 2). ${ }^{3}$ Looking at recent prices, it would take the seven-year

\footnotetext{
${ }^{2}$ Except where indicated, the source for data presented in this paper is the IMF's World Economic Outlook (WEO). Results reported are mostly for 62 oil-importing PRGFs: the four excluded cases are Liberia and Somalia (for which available data is insufficient) as well as Maldives and Timor Leste, which represent extreme outliers (with current account balance changes more than two standard deviations from the PRGF importers' mean). Oil exporters are excluded from the analysis, including countries, such as Bolivia, that export mostly gas.

${ }^{3}$ This study focuses on crude oil, but the prices of refined products that low-income countries may be more likely to import track crude oil prices extremely closely and tell much the same story.
} 
change between 1998 and 2005 (308 percent) to exceed the one-year increase of (252 percent) in $1974 .^{4}$

Although the magnitude of the recent shock relative to country economies appears similar to the shocks of the 1970s and 1980s, countries have been better positioned to deal with adverse conditions. At about 1 1/2 percent of GDP on average for low-income oil importers (measured as the change in the value of oil imports as a share of GDP), this shock is in line with earlier episodes. However, in addition to the more favorable global environment noted above, lowincome oil importers entered the most recent period with a higher level of reserves-roughly double the coverage ratios of the late $1970 \mathrm{~s}$ - providing more of a cushion before adjustment or additional borrowing became necessary.

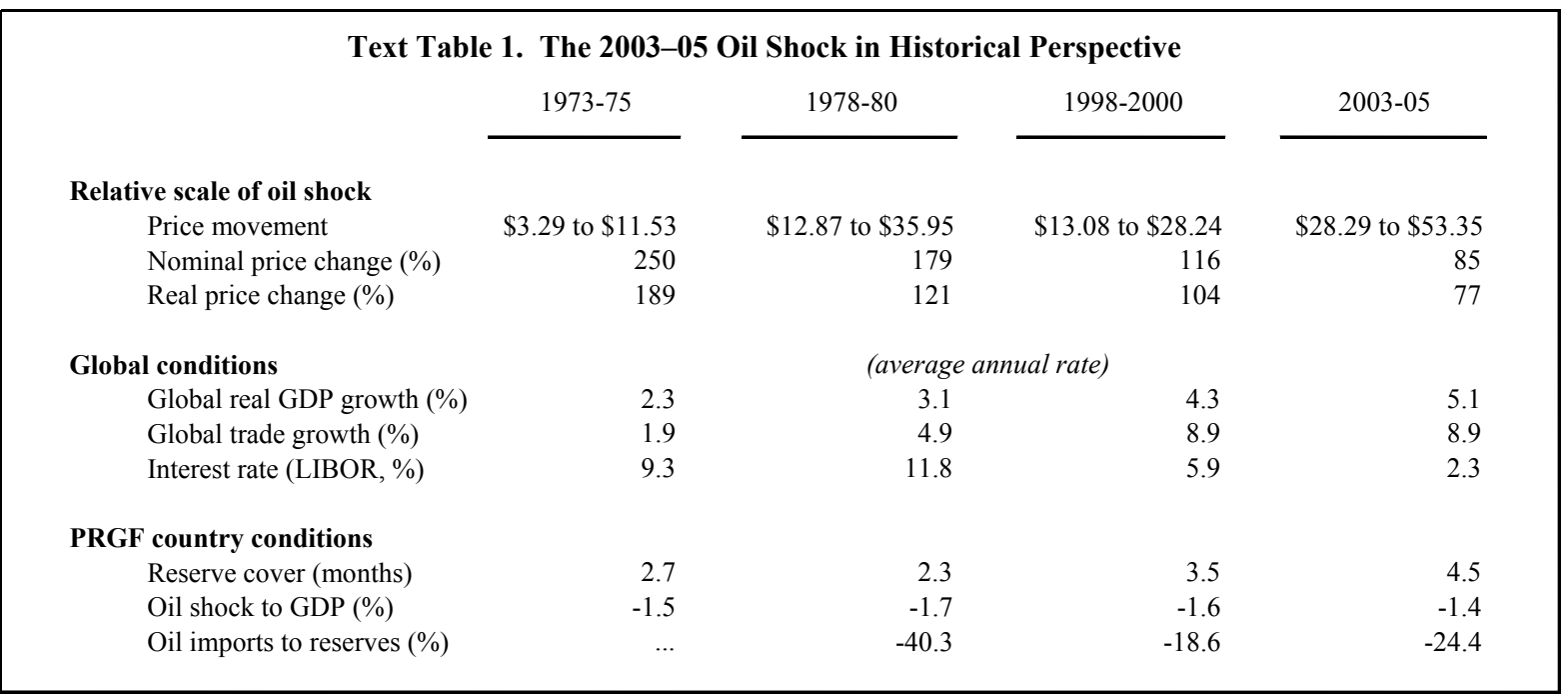

Two issues - namely oil intensity and exchange rates - did not appear to be factors in the scale of the shock. Oil intensity for PRGF oil importers fell by only 7 percent between 1973 and 2003, and thus offers limited insight into why the most recent price rise has not had a greater impact on low-income countries. In contrast, oil intensity for Organization for Economic Cooperation and Development (OECD) countries fell by 38 percent between 1973 and 2003. ${ }^{5}$ Likewise, exchange rate movements against the dollar, in which petroleum products are priced, varied but on average did not significantly appreciate or depreciate against the dollar.

\footnotetext{
${ }^{4}$ Using real oil prices also shows the most recent rise to be much more gradual than the spikes seen in the 1970s. Real oil prices based on the U.S. consumer price index $(2000=100)$ jumped by 217 percent in 1974 to $\$ 40$, by 110 percent in 1979 to $\$ 71$, and reached a high of $\$ 75$ in 1980 . This is in comparison to a 27 percent increase in prices in 2004 to $\$ 34$, and a 37 percent rise in 2005 to $\$ 47$.

${ }^{5}$ Oil intensity data were compiled by Paul Nicholson in the IMF's Research Department.
} 
Figure 1. Oil Prices and PRGF Financing

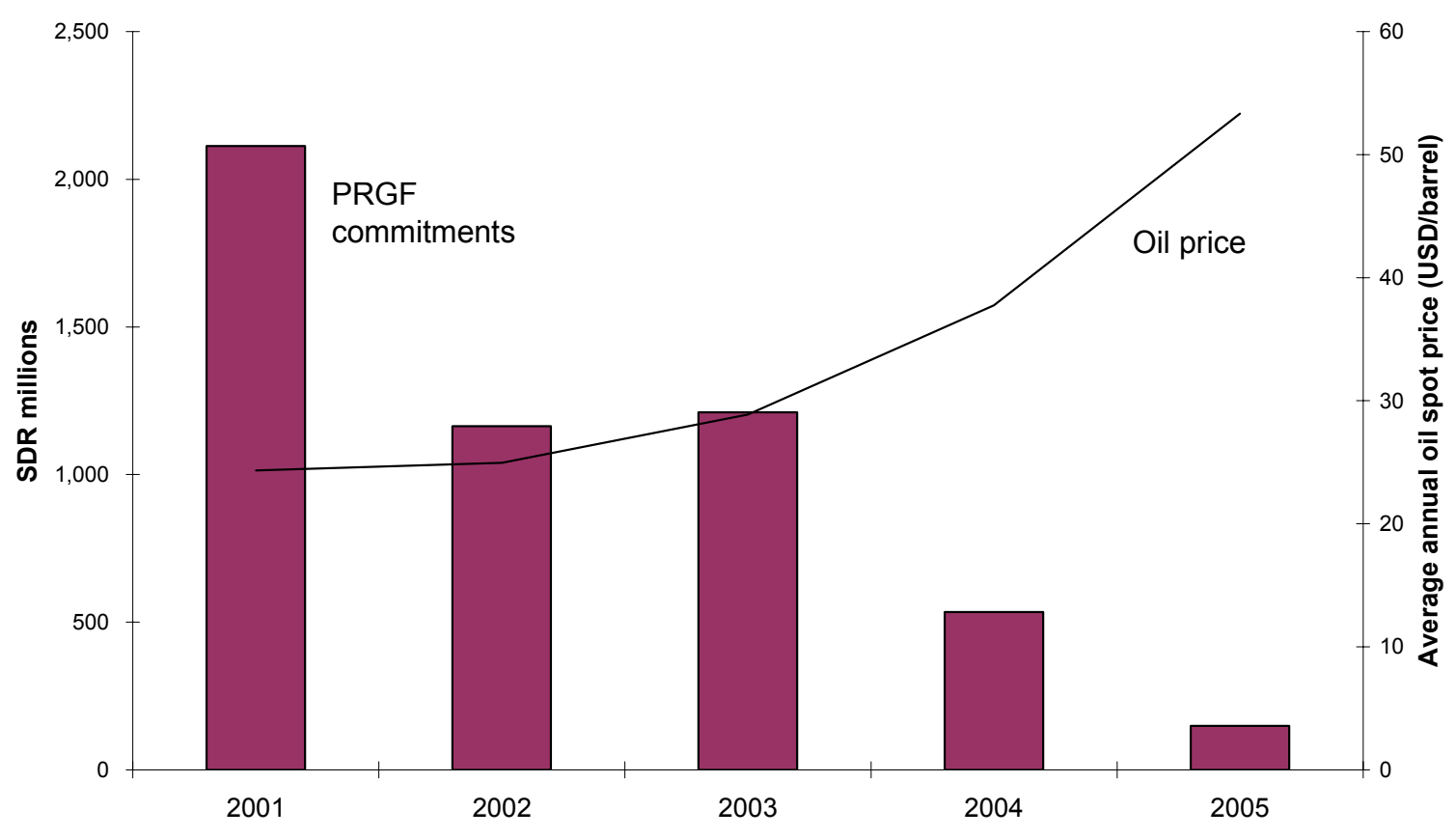

Sources: World Economic Outlook; IMF Finance Department.

Figure 2. Oil Prices and Annual Percentage Changes

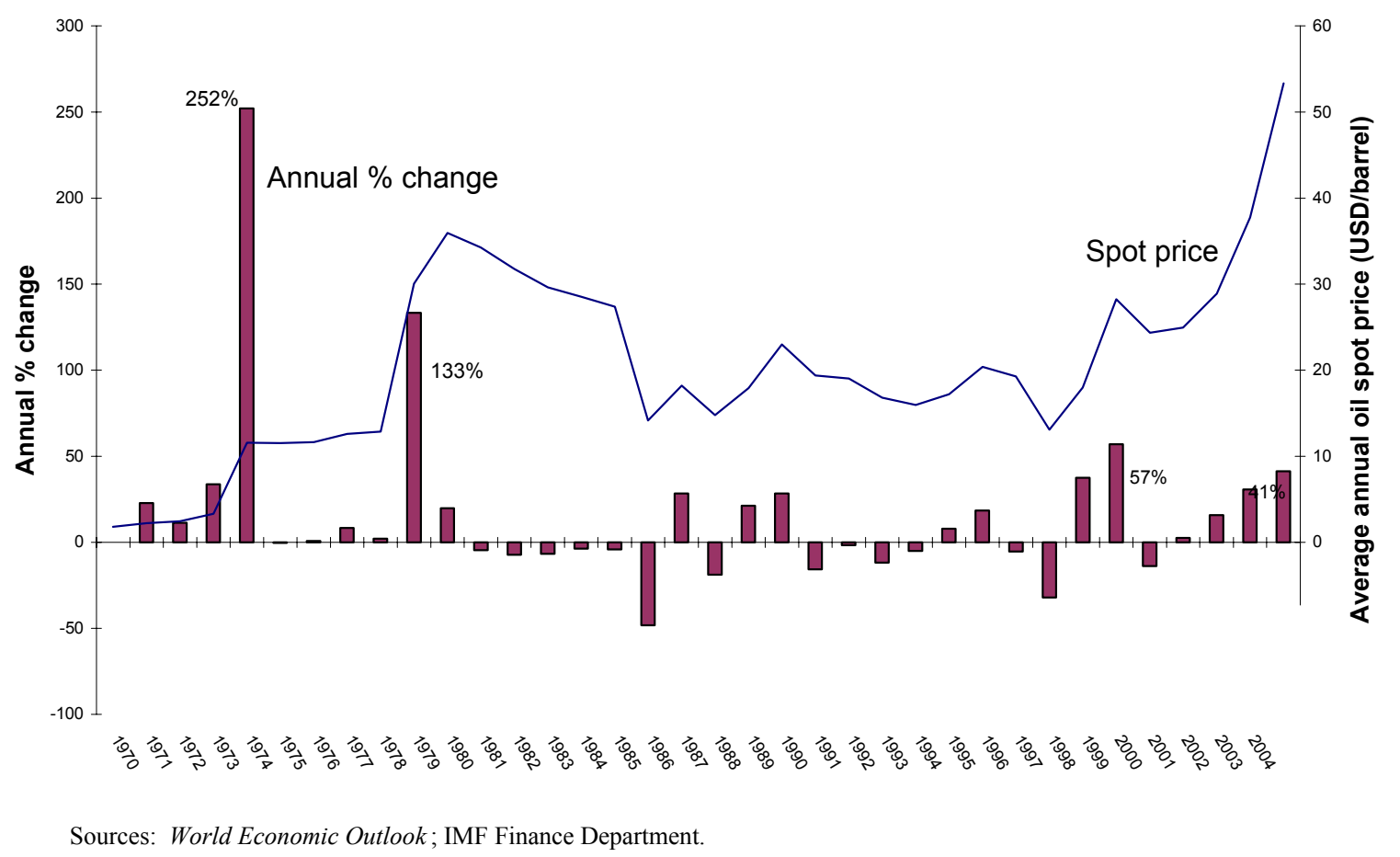




\section{Balance of Payments Impact}

The following section reviews the balance of payments impact of the oil shock from two perspectives. First, the average balance of payments impact is assessed for PRGF importers as a group, identifying the effect on the current account as well as on reserve levels. Comparisons with earlier periods of high oil prices, and with developments in middle income countries, are also examined. Second, this section explores cross-country differences in the impact of the oil shock to assess why the shock was so much larger in some countries than in others and identify the different means by which counries adjusted.

\section{A. Average Impact of the Oil Shock ${ }^{6}$}

The external current account balance of PRGF oil importers declined by 2.3 percent of GDP on average between 2003 and 2005. This reflected the following developments (see Text Table 2, and Tables 1 and 2 attached):

- $\quad$ Oil imports of the typical PRGF country increased by 1.4 percent of GDP, rising from an average of about 5 to $6 \frac{1}{2}$ percent of GDP. On a volume basis, however, oil imports appear to have fallen in a number of countries. ${ }^{7}$

- $\quad$ At the same time, exports rose on average by 1.7 percent of GDP, more than sufficient to fully cover the higher oil bill. This improvement
Text Table 2. Oil Shock Impact for PRGFs

Average changes between 2003 and 2005: (In percent of $G D P$ )

$\begin{array}{lr}\text { Current Account } & -\mathbf{2 . 3} \\ \text { Oil Imports } & -1.4 \\ \text { Exports } & 1.7 \\ \text { Non-oil imports } & -3.6 \\ \text { Other CA items } & 1.0 \\ \text { of } w \text { grants } & -0.2 \\ \quad & \\ \text { Capital Account } & \mathbf{3 . 0} \\ \text { by type of flows } & \\ \quad \text { FDI } & 0.5 \\ \text { Other Investment, net } & 2.6 \\ \quad \text { Other capital flows } & 0.0 \\ \text { by recipient } & \\ \quad \text { Official sector } & 0.1 \\ \text { Private sector } & 3.0\end{array}$

Reserves/ Overall BOP $\quad 0.7$

Note: Negative sign represents adverse BOP impact

\footnotetext{
${ }^{6}$ Some caveats apply to the WEO data on which this analysis is based. For many countries, data for 2005 are very preliminary and may be subject to substantial revisions. While the overall developments outlined here are unlikely to shift substantially, many of the specific magnitudes will change.

${ }^{7}$ The data on oil volumes are derived by deflating figures for the nominal value of oil imports with the change in world oil prices. This methodology gives a reasonable estimate of volume changes as long as the world oil price change roughly matches the oil price change faced by a particular country (countries may face different price levels depending on the particular product mix consumed, but the price changes are assumed to be broadly the same). However, some caveats apply. Notably, there may have been a rise in the underreporting of petroleum imports in the face of higher world prices due to customs corruption issues and smuggling of products from oil exporters with lower domestic prices. Also, some countries might have reduced inventories as prices rose, implying reductions in import volumes but not necessarily in oil consumption. Data for SubSaharan Africa are in particular inconclusive, with changes in volumes over a longer period not showing a significant link to world oil prices. This exercise estimated the reduction in oil volumes at 13 percent during 2003-05, although preliminary estimates by WEO show a 6 percent decline over the same period, which reflects the substitution of alternative oil price deflators in certain country cases.
} 
was due equally to price and volume effects.

- $\quad$ Non-oil imports rose by $3 \frac{1}{2}$ percent of GDP, which reflected stronger volume rather than price effects. This result indicates that despite the oil shock, there did not appear to be a compression of other imports.

- $\quad$ Other components of the current account (services, income, and transfers) picked up by 1 percent of GDP. Within this amount, official transfers remained largely unchanged.

The capital account of the typical PRGF oil-importing country registered a strong improvement during 2003-05. Net inflows rose from an average of 7 percent to 10 percent of GDP - an improvement that was sufficient to more than offset the current account deterioration. Higher official borrowing does not explain the capital account improvement. In fact, new official borrowing fell by about 1 percent of GDP during 2003-05 while debt stocks declined from 123 to 100 percent of GDP on average. ${ }^{8}$

A strong pickup in flows to the private sector, as well as debt relief, appears to account for the large capital account gains. Based on data from IMF staff reports, debt relief is estimated to have risen by 0.6 percent of GDP between 2003-05 reflecting both debt service and debt stock relief provided by the Heavily Indebted Poor Country (HIPC) Initiative. The largest volume of inflows, however, related to private sector transactions. These include Foreign Direct Investment (FDI), which rose by about $1 / 2$ a percent of GDP for the average oil importing PRGF country, as well as a combination of trade credits, private borrowing, and a drawdown of private foreign assets such as currency and deposits held abroad. ${ }^{9}$ The latter items taken together rose by an estimated 21/2 percent of GDP between 2003 and 2005, and thus played a substantial financing role during this period. A further decomposition of these inflows is unfortunately unavailable as they are reported jointly, and are typically a residual in the balance of payments accounts recorded by WEO. It is possible that these flows in part include unidentified private transfers and remittances that are not captured elsewhere in the balance of payments.

As a result, despite the adverse oil shock, the reserve position of PRGF countries improved on average during 2003-05. Reserve levels, expressed relative to GDP, rose by an average of 0.7 percent of GDP, although coverage ratios fell on average from 4.7 to 4.2 months of coverage during this period, reflecting the spike in imports.

Based on this average PRGF experience, the two key factors mitigating the impact of the oil shock have been the rise in exports and the capital account improvement. Interestingly, according to OECD data, official development assistance (including grants) from bilateral and multilateral donors to oil-importing PRGF countries is estimated to have declined

\footnotetext{
${ }^{8}$ Debt data are from WEO, but are corroborated by data from other sources, including IMF country reports and the World Bank's Global Development Finance Report.

${ }^{9}$ Almost two thirds of countries experienced an increase in private sectors flows as a share of GDP, although the averages are in part influenced by small island economies (see Table 1).
} 
slightly as share of GDP. Overall, despite the fall in grants, debt ratios fell, reflecting in large part greater debt relief.

As outlined in Appendix I, several key issues distinguish balance of payments developments under the current oil shock from the previous episodes of high oil prices in 1973-75 and 1978-80. First, while the magnitudes of the shocks as a share of GDP were broadly similar, shocks in the earlier periods were not offset by higher exports as they were in 2003-05. As a result, overall current account deficits were higher during the earlier periods. Second, the strong capital inflows during the earlier shocks were primarily composed of additional borrowing, and countries' indebtedness increased markedly. Finally, reserve positions expressed relative to GDP deteriorated during the earlier shocks, but have improved during the current shock.

Comparing balance of payments developments in LIC oil importers and middle income oilimporting countries during 2003-05 suggests a broadly similar experience. ${ }^{10}$ As a share of GDP, the scale of the shock was similar in the middle income countries (1.7 percent of GDP), but was offset by even higher exports (3.2 percent of GDP), compared to the results for LICs in Text Table 2 above. Developments in other components of the current account were similar between the two groups of countries, although the capital account and reserves improvements were more limited in the middle-income countries.

\section{B. Cross-Country Differences}

The aggregate relationships summarized above mask some important variations in country experiences. In particular, we find that the impact of the oil shock and country responses fall into four broad categories (Figure 3 and Text Table 3):

- For 16 countries - close to 30 percent of PRGF importers - there was a decline in the oil import bill relative to GDP owing to what appears to have been a particularly sharp contraction in the volume of oil imports. The oil price rise did not lead to an adverse impact on the balance of payments for this set of countries, as they saw improvements in both the current and capital accounts during 2003-05 that translated into a strengthening of the reserve position.

- Another 12 countries faced higher oil imports, expressed in relation to GDP, but benefited from substantial current account offsets in the form of improved exports, services, and/or grant receipts. Together with gains in the capital account, this subgroup also saw a strong overall improvement in the reserve position.

- For a third category of 12 countries, they faced both higher oil imports and a worsened current account, but a substantial improvement in the capital account allowed for a net improvement in the reserve position.

\footnotetext{
${ }^{10}$ The WEO does not define middle income economies. This paper used the set of countries that do not fall under the WEO definitions of "advanced economies," "least developed countries," or "oil exporters," and are not classified as PRGF-eligible.
} 
- The remaining 22 PRGF importers benefited from neither current account nor capital account improvements sufficient to offset the oil shock and thus saw a deterioration in their overall reserve position. Within this group, however, a majority of cases maintained relatively comfortable reserve coverage levels ${ }^{11}$ and could thus accommodate the drawdown in reserves. Only in a sub-set of seven countries did reserves fall to very low levels: two of these cases requested a PRGF augmentation (Bangladesh and Madagascar); three cases are in the process of moving towards a PRGF arrangement (Cambodia, Djibouti, and Tajikistan); and the remaining two cases (Kiribati and Zimbabwe) have no PRGF prospects at present. ${ }^{12}$

The varied cross-country experience described above is noteworthy on two counts. First, the decline in oil imports relative to GDP for such a large number of cases shows that oil volume reductions have likely been a dominant form of adjustment by low income countries, a topic which is further explored below. Second, the degree of offsets provided by other current and capital account items is clearly an important determinant of whether the country experiences overall reserve losses, and thus the variance across countries in the capital account is also explored. Issues related to economic growth are discussed in Box 1.

\footnotetext{
${ }^{11}$ As measured by a reserve cover exceeding three months of imports.

${ }^{12}$ Maldives has benefited from access under the Emergency Natural Disasters Assistance following the end2004 tsunami while Kiribati has never sought Fund resources.
} 
Figure 3. The 2003-05 Oil Shock and Its Impact on PRGF-Eligible Countries

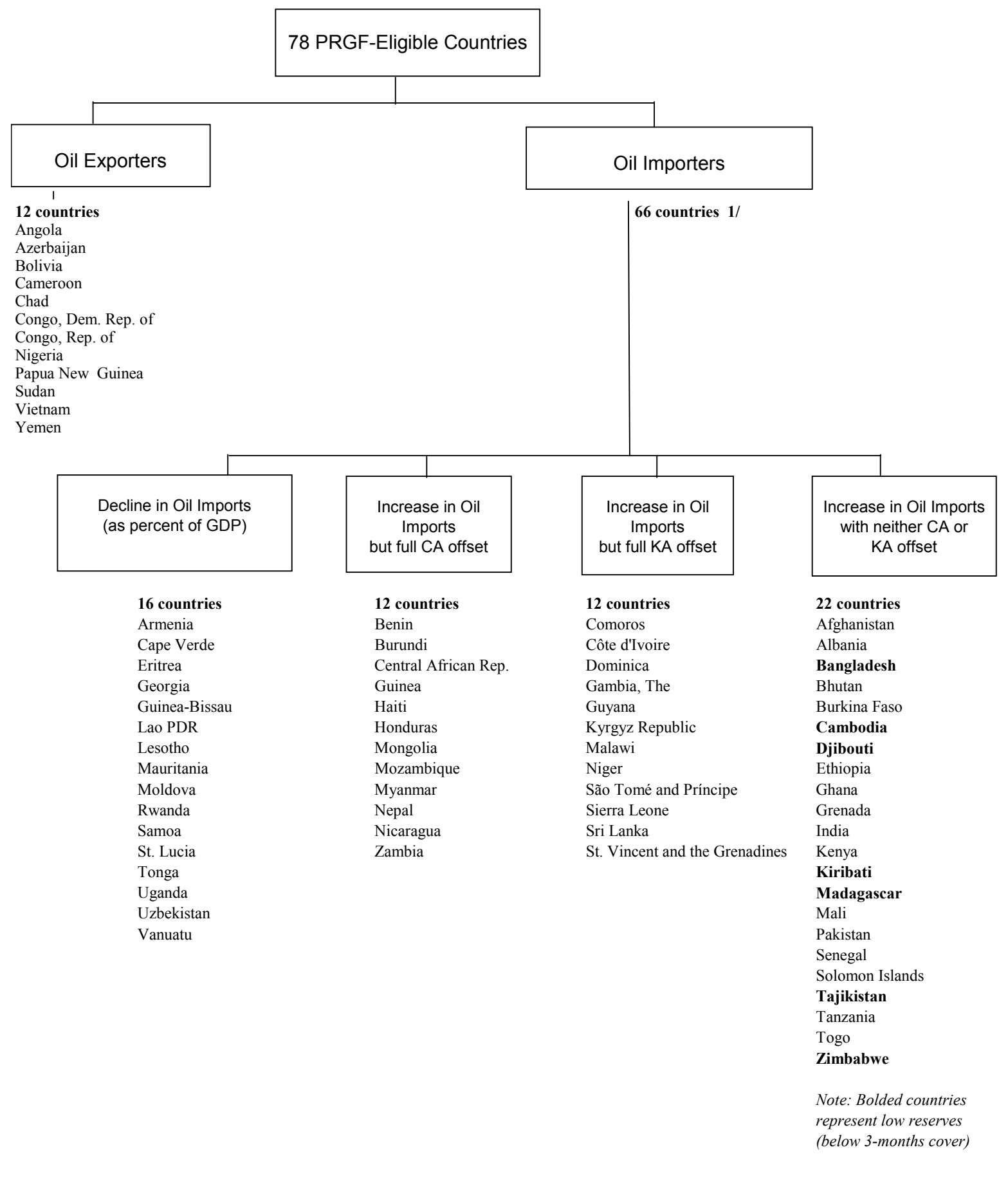

1/ From the 66 oil importers, four countries are excluded: Liberia and Somalia (due to insufficient data) and Maldives and Timor Leste (which represent extreme outliers).

2/ Three of the four PRGF access augmentations during 2003-05 were to countries hit by the oil shock and that faced balance of payment losses; the fourth country (Niger) received an augmentation due to a drought-related balance of payment shock. 


\begin{tabular}{|c|c|c|c|c|c|}
\hline \multicolumn{6}{|c|}{$\begin{array}{c}\text { Text Table 3. Summary Data for PRGF Country Groupings } \\
\text { (In percent of } G D P \text { ) }\end{array}$} \\
\hline & $\begin{array}{l}\text { All PRGF } \\
\text { Importers }\end{array}$ & $\begin{array}{l}\text { Sharp Vol } \\
\text { Adjustors }\end{array}$ & $\begin{array}{l}\text { Ctries } w / \\
\text { CA offsets }\end{array}$ & $\begin{array}{l}\text { Ctries w/ } \\
\text { KA offsets }\end{array}$ & $\begin{array}{l}\quad \text { Ctries w/ } \\
\text { neither CA } \\
\text { nor KA offsets }\end{array}$ \\
\hline & {$[62]$} & {$[16]$} & {$[12]$} & {$[12]$} & {$[22]$} \\
\hline \multicolumn{6}{|l|}{ Responses to Oil shock 1/ } \\
\hline$\Delta$ Oil imports: & -1.4 & 1.1 & -1.9 & -3.5 & -1.8 \\
\hline$\Delta \mathrm{CA}:$ & -2.3 & 0.2 & 3.0 & -5.1 & -5.5 \\
\hline$\Delta \mathrm{KA}:$ & 3.0 & 3.0 & -0.9 & 9.1 & 1.8 \\
\hline$\Delta \mathrm{BOP}:$ & 0.7 & 3.2 & 2.1 & 4.1 & -3.7 \\
\hline \multicolumn{6}{|l|}{ Initial Conditions, 2003: } \\
\hline Oil intensity: & 5.0 & 5.3 & 4.3 & 6.3 & 4.4 \\
\hline Reserve cover (mths): & 4.7 & 4.3 & 4.2 & 4.4 & 5.5 \\
\hline \multicolumn{6}{|l|}{ Other indicators 2/ } \\
\hline Real GDP growth: & 4.7 & 5.3 & 4.0 & 3.6 & 5.3 \\
\hline Terms of trade: & -2.9 & -0.6 & 3.2 & -6.6 & -5.6 \\
\hline Oil import volumes: & -6.7 & -21.1 & -1.1 & 2.0 & -3.8 \\
\hline
\end{tabular}




\section{Box 1. The 2003-05 Oil Shock and Its Impact on Growth}

The 2003-05 oil shock has not been associated with any marked shifts in the average economic growth performance of PRGF importers. Average growth rates rose from 4.2 percent in 2003 to 4.5 percent in 2005, but the country experience was quite varied as the number of cases where growth rates fell roughly matched the number of instances in which growth rates rose. While growth might have been stronger had oil prices not risen so sharply, the extent of higher growth under such a counterfactual scenario is difficult to ascertain.

The continuation of the growth momentum in PRGF countries reflected both external and internal factors. As noted earlier, global growth provided increased support to exports by PRGF economies, as trading partners' import demand grew by an average of 7 percent in 2005, compared to 5 percent in 2003. Rising investment activity in PRGF countries - reflected in investment ratios climbing from 21 to 23 percent of GDP on average - further boosted economic growth during this period.

\section{With respect to differences in growth rates among low income oil-importers:}

- Despite the oil shock, growth rates have come to show much less variance, reflecting fewer cases of low/negative growth in 2005 than in 2003. The latter outcome appears to reflect the fact that strong global conditions more than offset the impact of the oil shock in those countries where growth was below the norm in 2003.

- A simple comparison of growth performance across the various country groupings (identified in Figure 3) suggests that growth has not been affected by the degree of adjustment in oil imports. In particular, average growth during 2003-05 in countries with sharp adjustments in oil volume was roughly similar to that in countries that relied on reserves drawdowns; moreover, looking at growth trends over time, countries with sharp adjustments in oil imports showed improving growth rates between 2003 and 2005, in contrast to deteriorating outturns seen for those countries that relied on reserves drawdowns.

- Econometric tests did not find evidence that growth was affected by adjustments in oil import volumes. These adjustment do not seem to have affected growth even after controlling for other typical determinants (for instance, expenditure in education the previous year, investment as a percentage of GDP, and the change in the terms of trade). For each country, a growth accounting exercise was also carried out covering the period 1975-2002 (or the earliest period after 1975 for which data is available). GDP growth for 2004 and 2005 was then predicted for each country and the discrepancy between the predicted and the actual rate of growth was considered. In the framework of growth accounting, this discrepancy captures the impact of shocks to total factor productivity. No relationship was found between oil volume adjustments and discrepancies between actual and predicted growth rates, even after controlling for changes in the terms of trade. 
Regarding the determinants of oil volume adjustment, a cross-country econometric analysis was carried out (see Appendix II) to examine the relationship between changes in oil import volumes between 2003 and 2005, and variables such as real GDP growth, the terms of trade, oil intensity, and the degree of oil price pass-through. Under many specifications, no strong evidence emerged pointing to a unique pattern explaining oil volume adjustments: for example, countries with sharp volume cutbacks did not show systematically lower growth. As a further review, the elasticity of oil import volumes to the oil price, income, and the nonoil terms of trade was estimated for three different time periods: 1965-2000, which is suitable to study long-run elasticity; 1980-99, a period when oil prices oscillated nominally but declined in real terms; and 2000-05, a period of steady nominal and real increases in oil prices. The main finding is that the estimated price elasticity in 2000-05 was almost the same as in the long-run and half the elasticity in 1980-99.

The determinants of cross-country differences in borrowing were also explored. This work looked at the change in borrowing as a percentage of GDP between 2003 and 2005, and regressed it for the group of oil importers over the change in oil volumes (barrels per unit of output), the change in the terms of trade, the change in grants as a percentage of GDP, and the change in the non-oil current account as a percentage of GDP. The results showed that while overall borrowing by LICs as a group has declined, countries that borrowed more were those with larger (non-oil) current account deficits and smaller reductions in oil import volumes (see Table 3 of Appendix II).

\section{FISCAL IMPACT}

Higher oil prices can have a fiscal impact through a number of channels, as outlined below. Which costs, if any, materialize will depend on oil pricing and tax regimes and policies; the scale of the costs is a function of the degree of price pass-through and subsidy decisions. ${ }^{13}$

- $\quad$ On the expenditure side, there can be fiscal costs when oil-importing countries do not adjust domestic petroleum product prices. These could take the form of quasi-fiscal losses - for example, as distribution margins of national oil companies may be squeezed — or through direct subsidies paid to such companies.

- $\quad$ Costs may also arise when domestic prices adjust to world oil prices to the extent that governments raise social benefits payments or other transfers to moderate the impact on consumers. As well, the public sector would have to pay more for the petroleum products it consumes.

\footnotetext{
${ }^{13}$ There are also potential social costs of petroleum product price increases. These costs are not the focus of this paper, but would include poor targeting of explicit petroleum price subsidies and distorting effects on the allocation of resources.
} 
- On the revenue side, fuel tax collection is affected by the degree of price passthrough. When domestic demand for petroleum products is price-elastic, fuel tax collection may fall, especially when petroleum products are subject to a specific tax.

- $\quad$ Lowering fuel taxation to mitigate the impact of higher world market prices for petroleum products may be another source of revenue loss.

The budgetary impact of the oil shock for oil-importing PRGF countries was either low or offset by other fiscal developments. The average overall fiscal balance improved by more than half a percent of GDP per year in 2003-05 (see Figure 4 below). The average primary deficit - which excludes interest payments and thus the impact of debt relief during this period - improved moderately, from an average of $2 \frac{1}{2}$ percent of GDP in 2003 to about 2 percent of GDP in $2005 .{ }^{14}$ The fact that fiscal balances improved on average does not necessarily mean that the fiscal impact of the oil shock was minor in every country. Several countervailing policy actions might have been taken-for example, far reaching tax reforms in the case of Georgia - and not all of them linked to the oil price shock.

An important factor contributing to the

Figure 4. Oil Impact and Overall Fiscal Balance, 2003-05 (Annual average change, in percent of GDP)

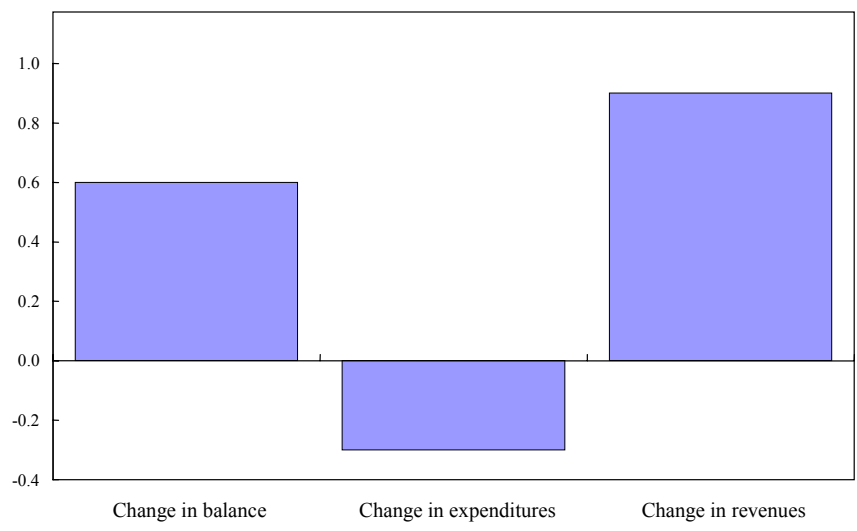
positive fiscal outcome seems to be that most oil-importing PRGF countries are net fuel tax recipients and have passed-through the oil price shock. Most countries rely on petroleum taxation for fiscal revenue, and do not explicitly subsidize domestic retail fuel prices (Box 2). ${ }^{15}$ As a result, many of these countries have had a strong incentive to pass-through world prices to domestic retail prices to increase petroleum tax revenue. Domestic retail fuel prices (in U.S. dollar terms) have remained above the world market price for crude oil as well as the U.S. retail price for gasoline between end-2002 and mid-2005, and over this period, have increased by more than the U.S. equivalent in more than three-quarters of the PRGF countries in the sample (Figure 5). Pass-through ratios (defined as the change of the domestic retail gasoline price over the change in the U.S. retail gasoline price) are larger than one for these countries (Table 3 attached). ${ }^{16}$ However, regional differences remain. African countries

\footnotetext{
${ }^{14}$ The overall balance averages are based on a sample of 58 countries. The primary balance averages are based on a subset of 48 countries for which data were available.

${ }^{15}$ By contrast, many oil-producing countries subsidize domestic retail prices.

${ }^{16}$ The calculation of the pass-through ratios assumes that transportation, distribution, and marketing costs remain constant during 2003-05. The U.S. is chosen as the comparator market because fuel tax rates in PRGF countries, typically between $30-40$ percent, are closer to the U.S. level including road fund contributions, while European tax rates are above 60 percent.
} 
have had the highest retail fuel prices and pass-through ratios, while CIS countries have had the lowest (Table 4 attached).

\section{Box 2. Fuel Tax Regimes}

Net oil importing countries apply a wide range of taxes on petroleum products, including VAT or sales taxes, specific excises, and customs duties. Evidence from a small sample of 22 countries suggests that few countries have changed fuel taxation such that it lowered tax revenues. Ten countries raised customs duties or excise rates to boost revenues, partly to fund increased spending. Some did so to help curb oil consumption. Among PRGF-eligible countries, some have eliminated import duties (Zambia) or introduced VAT exemptions (Sri Lanka) to control the increase in domestic fuel prices.

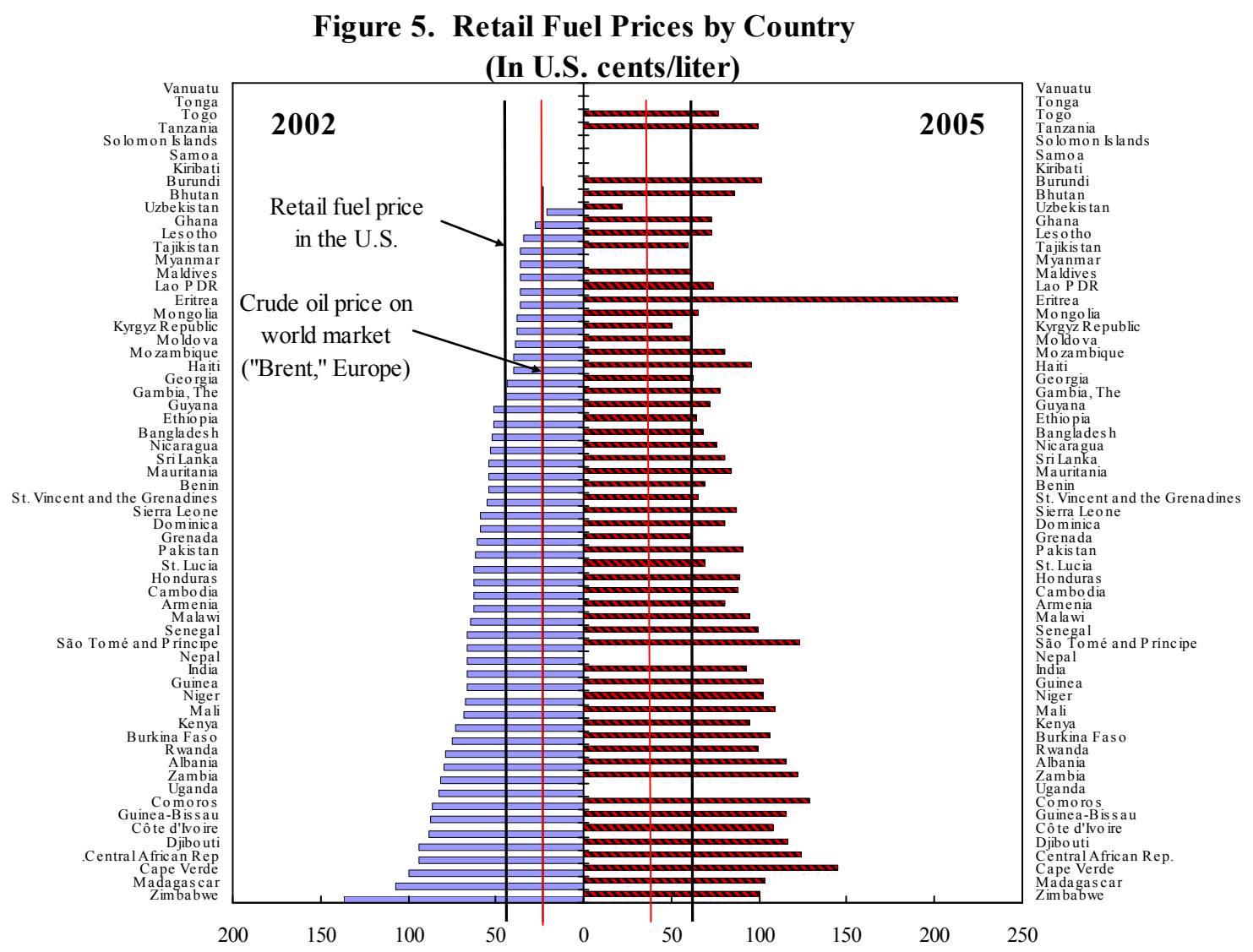

Sources: www.International-Fuel-Prices.com; gerhard.metschies@gmx.de; and Fund staff estimates.

High pass-through ratios for U.S. dollar prices of gasoline are largely mirrored for diesel fuel, but less so for kerosene. Pass-through was widely observed for diesel fuel through end2004 (Figure 7), while for kerosene, pass-through ratios were lower at about 60 percent for a small sample of countries for which data were available. This would be consistent with the policy in some low-income countries to subsidize (or tax less heavily) kerosene, which is disproportionately consumed by poorer households. At the same time, consumption volumes 
of kerosene are small compared to other fuel products even in low-income countries (Figure 6). Therefore, the fiscal costs of subsidization are likely to be small as well.

Figure 6. PRGF Countries' Petroleum Products Consumption, 2003

(Averages, in percent of total consumption)

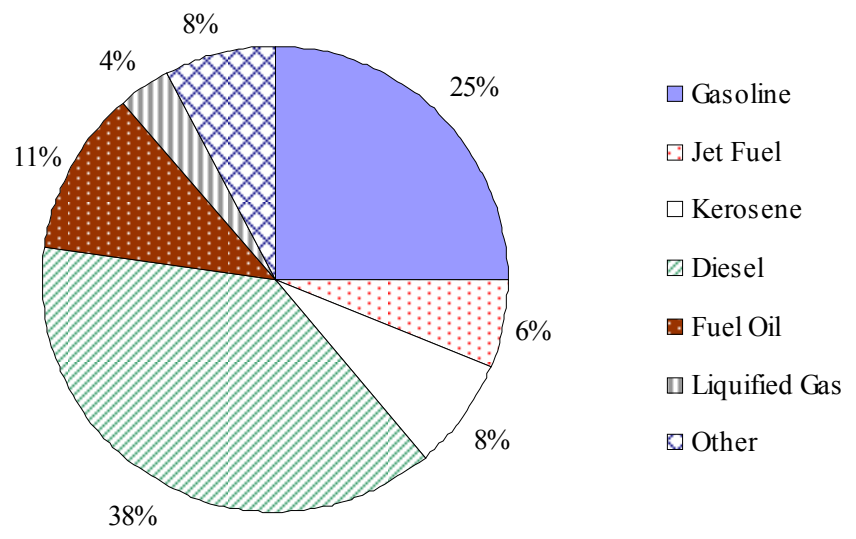

Source: Energy Information Administration, Official Energy Statistics from the U.S. Government. 
Figure 7. Retail Prices of Diesel in PRGF Countries (As of November 2004 in U.S. cents per liter)

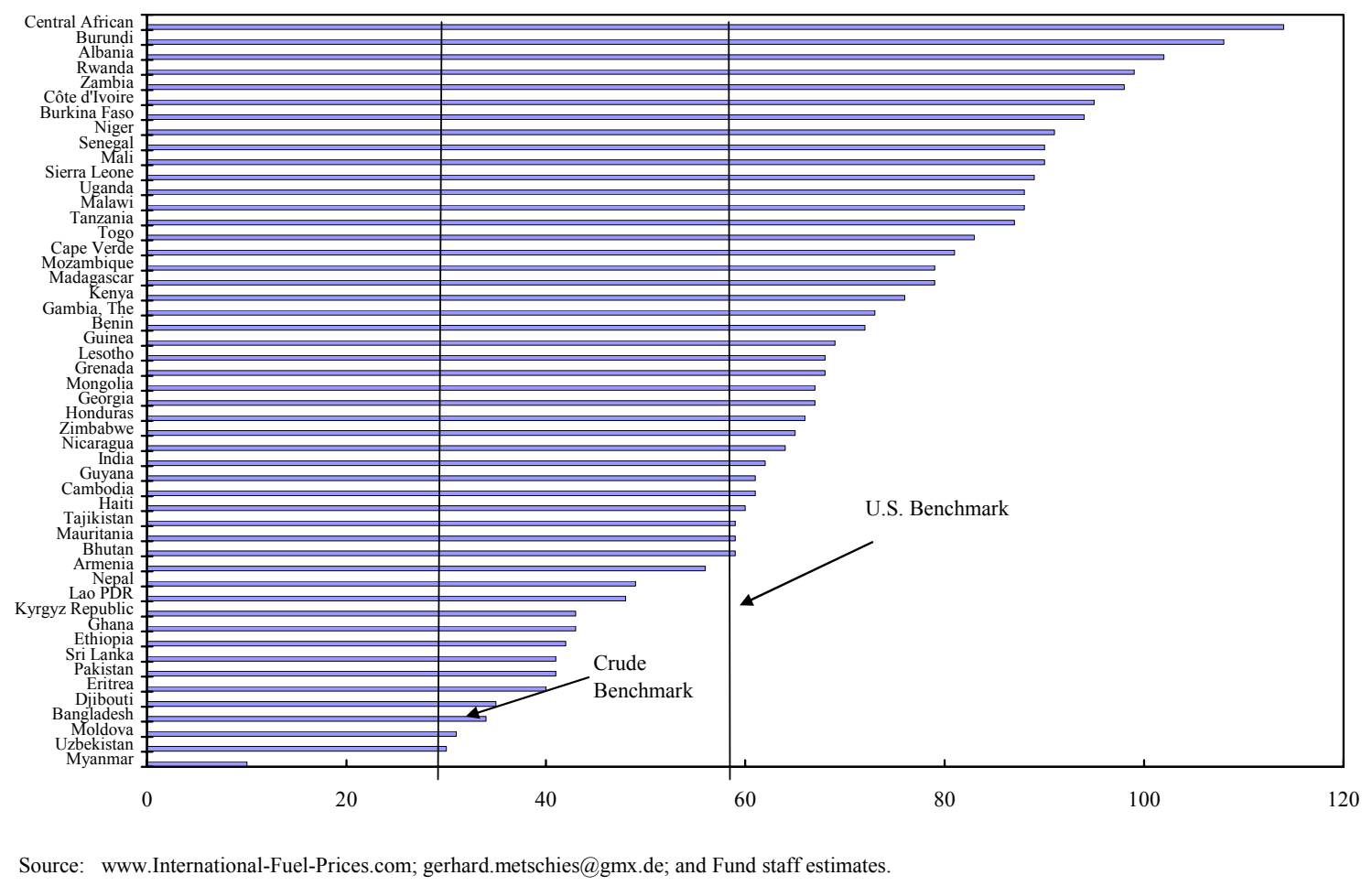

This outcome seems to be confirmed when analyzing fiscal developments in the non-passthrough countries separately. Fiscal developments were worse in these countries. While the pass-through countries saw revenues increase by almost one percent of GDP per year, the non-pass-through countries witnessed a decline, although neither group of countries saw their overall balance decline as share of GDP (Figure 8). Despite declining expenditures, however, some of the countries could still be explicitly subsidizing oil products. This would imply a potentially significant change in expenditure composition, as other expenditures are replaced with fuel subsidies.

While fiscal balances have on average not been negatively affected by the oil price shock, fiscal improvements in the pass-through countries could have been stronger and there may be a build-up of liabilities in the quasi-fiscal sector. About half of the PRGF countries for which data are available have relaxed the taxation of petroleum products in 2003-05 to help absorb the oil price shock. Moreover, subsidization may not be sustainable for the non-pass-through countries if the oil price shock is permanent. Finally, the public enterprise sector-whose financial balances are not included in the fiscal indicators for many countries - may be building liabilities to the extent that they do not adjust their output prices in line with energy prices. These liabilities would not only accumulate in the oil sector. For example, financial balances of public utilities would deteriorate if their prices and tariffs are not adjusted while petroleum product input prices are rising. 
Figure 8. Oil Price Shock and Overall Balance, 2003-05 (Annual average change, in percent of GDP)
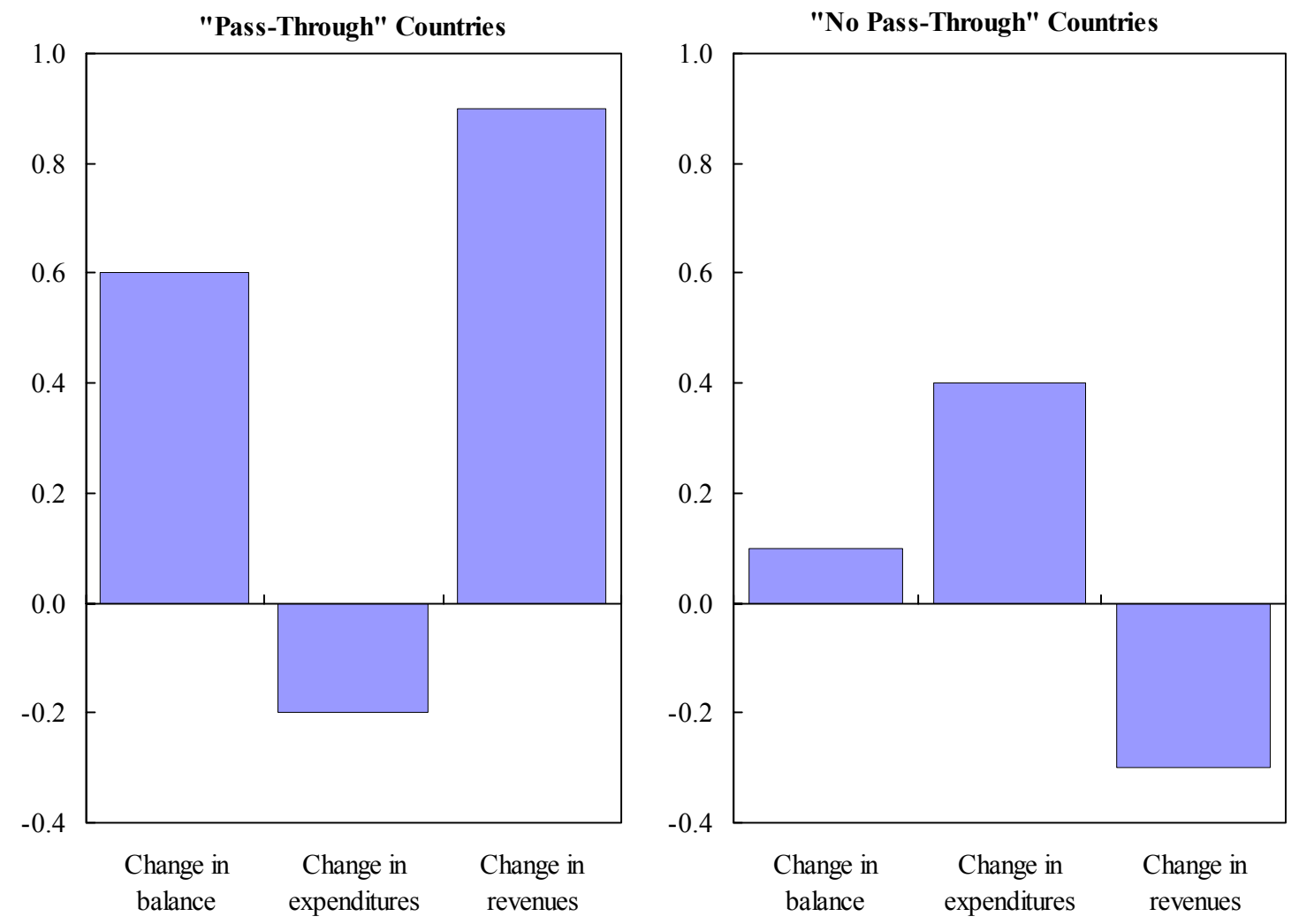

Note: "No pass through" countries excludes Zimbabwe. 


\section{LOOKING FORWARD-POSSIBLE VULNERABILITIES}

This section examines the outlook for PRGF countries in light of the continued rise in oil prices during 2006. World oil prices are currently well above the average price for 2005, and WEO projections indicate that these prices are expected to remain near current levels for some time, with some risk that they could increase further. These developments raise concerns about increased vulnerabilities and the pace of adjustment in LIC oil importers. In particular, there may be little room for further compression of import volumes of petroleum products without some negative impact on growth. At the same time, if countries do not adjust, and higher imports of petroleum products lead to a loss of reserves, additional countries could be more vulnerable.

Recent WEO projections for LIC oil importers suggest a different picture in 2006 compared to 2003-05. In the baseline scenario (Scenario A of Text Table 4, which reflects current WEO projections), the current account would not be adversely affected, as oil imports would rise moderately, but by much less than the 2 percent of GDP rise in exports. Non-oil imports would remain broadly stable. However, a reversal in capital flows is projected, as the large improvement registered by most countries during 2003-05 (on the order of near 3 percentage points of GDP) is not expected to be sustained. Indeed, PRGF oilimporters as a group are expected to show net capital outflows during 2006 which, together with a relatively unchanged current account, would result in reserves falling by 0.7 percent of GDP.
Text Table 4. Oil Shock Impact for 2005-06 (In percent of GDP)

\begin{tabular}{|c|c|c|}
\hline & $\begin{array}{c}\text { Scenario } \\
\text { A }\end{array}$ & $\begin{array}{c}\text { Scenario } \\
\text { B }\end{array}$ \\
\hline Current Account & 0.2 & -0.4 \\
\hline Oil Imports & -0.3 & -0.9 \\
\hline Exports & 2.0 & 2.0 \\
\hline Non-oil imports & -0.2 & -0.2 \\
\hline Other CA items & -1.2 & -1.2 \\
\hline$o / w$ grants & -0.7 & -0.7 \\
\hline Capital Account & -0.9 & -0.9 \\
\hline FDI & -0.4 & -0.4 \\
\hline Other Inv., net & -0.2 & -0.2 \\
\hline Other KA & -0.3 & -0.3 \\
\hline Reserves/Overall BOP & -0.7 & -1.3 \\
\hline \multicolumn{3}{|c|}{$\begin{array}{l}\text { Note: Negative sign represents adverse BOP impact } \\
\text { Scenario A: Based on } \$ 61.25 \text { oil price for } 2006 . \\
\text { Scenario B: Based on } \$ 66.5 \text { oil price for } 2006 \text {, } \\
\text { other BOP projections unchanged, and } \\
\text { countries resorting to reserve draw downs. }\end{array}$} \\
\hline
\end{tabular}

Updating these projections with the latest oil price projection for 2006 suggests that the adverse impact could be more significant (Scenario B of Text Table 4). ${ }^{17}$ Under this scenario, countries are assumed not to adjust to the higher prices by reducing import volumes

\footnotetext{
${ }^{17}$ Oil price projections for 2006 have increased— to $\$ 66.50$ per barrel—since the Spring 2006 WEO.
} 
further, and instead see an additional drop in reserves of $1 / 2$ percent of GDP. ${ }^{18}$ About two dozen countries would experience reserve declines this year that could be attributable in part to the oil price increase, although - using a reserve cover of three months of imports as a threshold - only about six countries (Bangladesh, Eritrea, Guinea, Guyana, Haiti, and Moldova) would potentially see reserve cover fall below this level. ${ }^{19}$ Some of these countries currently have program arrangements with the Fund and others might consider such arrangements in order to secure (increased) resources to cover anticipated financing gaps. Domestic policy adjustments as well as funding from other external sources would also be options.

\section{CONCLUSIONS AND IMPLICATIONS FOR DEMAND FOR IMF RESOURCES}

As discussed above, the global context has helped mitigate the impact of the current rise in world oil prices. The increase in world oil prices has been more gradual and smaller in percentage terms than during earlier episodes, while global growth and trade have been higher, consistent with the demand-side pressures that characterize this shock. This has given countries time to adjust, which many did as petroleum import volumes contracted in reaction to the pass-through of world oil prices to domestic retail prices. At the same time, exports picked up in many low-income countries, in large part due to higher world prices, driven by strong world demand. On average, the rise in exports offset the portion of the oil shock that was not offset by lower import volumes.

At the same time, current account deficits widened as a result of rising non-oil imports by LIC oil importers in 2003-05, indicating that countries did not adjust to the oil shock through a compression of other imports. Instead, more positive capital account developmentsreflecting FDI, debt relief, and other capital inflows - helped cover the wider current account deficits. Some countries reduced reserve coverage moderately to finance the remaining gap.

In this setting, there has not been an increase in demand from LICs for Fund resources. This demand would have been seen through requests for increased access or "augmentation" under an existing PRGF program, requests for access under a new PRGF, or requests for support under the Exogenous Shocks Facility (ESF). ${ }^{20}$ To date, there have been no requests under the ESF and few requests for PRGF augmentations, while overall PRGF commitments and disbursements have fallen even as oil prices have risen. Moreover, while IMF programs over this period have likely been designed with the impact of the oil shock in mind, there has not been an increase in waivers in IMF programs as a result of financial targets being missed due to the oil shock.

\footnotetext{
${ }^{18}$ The assumptions of Scenario B, involving no additional adjustment in either oil import volumes or other components of the balance of payments, should set an outer limit to the impact of the oil shock.

${ }^{19}$ This list of six countries excludes those whose reserve coverage was already below three months of imports.

${ }^{20}$ The ESF has been in place since January 2006.
} 
The lack of demand for additional Fund resources may reflect several broader factors beyond the specific balance of payments developments examined in this paper. First, as is the case for other forms of Fund financing, PRGF commitments have been on a downward trend in recent years. This reflects, in part, successive rounds of debt relief and perhaps better country policies, as well as some countries moving to low-access PRGF arrangements (although it does not appear to reflect higher levels — as a percent of GDP — of development grants and loans). Second, as noted above, averages obscure individual country circumstances, and it could be the case that some of the countries that experienced a deterioration in their balance of payments positions might have sought assistance but were unable to obtain it for other reasons. For example, a number of PRGF-eligible countries are unlikely to have the needed strength of policies (the Upper Credit Tranche-UCT-standard) to qualify for IMF support. This group includes countries that have had chronically weak policy performance in recent years, such as Zimbabwe and Eritrea, as well as countries that are striving to improve policies, including under Staff Monitored Programs (e.g., GuineaBissau and the Comoros). Third, a number of lower middle-income countries that might be attracted to the concessional resources of the PRGF or ESF are ineligible because they are above the income threshold for access to these resources.

With world oil prices continuing to rise to levels now substantially above the average price used in this paper for 2005, balance of payments developments in LICs merit close attention. If world oil prices remain at current levels or increase, it is possible that more LICs will approach the IMF for financial support. Likewise, if some of the mitigating factors, such as strong global growth and export prices recede, LICs could be under greater stress. 
Table 1. Impact of Higher Oil Imports for PRGF-Eligible Countries: 2003-05 (In percent of GDP)

\begin{tabular}{|c|c|c|c|c|c|c|c|c|}
\hline $\begin{array}{c}\text { Change in } \\
\text { Current Account }\end{array}$ & $\begin{array}{l}\text { Change in } \\
\text { Oil Imports }\end{array}$ & $\begin{array}{l}\text { Change in } \\
\text { Rest of CA }\end{array}$ & $\begin{array}{c}\text { Change in } \\
\text { Non-oil Exports }\end{array}$ & $\begin{array}{c}\text { Change in } \\
\text { Non-oil Imports }\end{array}$ & $\begin{array}{c}\text { Change in } \\
\text { Other CA Items }\end{array}$ & $\begin{array}{l}\mathrm{o} / \mathrm{w} \\
\text { Grants }\end{array}$ & $\begin{array}{c}\text { KA Change } \\
03 \text { vs } 05\end{array}$ & $\begin{array}{c}\text { Overall BOP } \\
03 \text { vs } 05\end{array}$ \\
\hline
\end{tabular}

\begin{tabular}{|c|c|c|c|c|c|c|c|c|c|}
\hline Average & -2.3 & -1.4 & -0.9 & 1.7 & -3.6 & 1.0 & -0.2 & 3.0 & 0.7 \\
\hline \multicolumn{10}{|c|}{ IMPORTERS ONLY (66) } \\
\hline 1 Afghanistan & -2.5 & -0.6 & -1.9 & -15.5 & 15.4 & -1.8 & -9.9 & -0.4 & -2.9 \\
\hline 2 Albania & -0.1 & -0.3 & 0.2 & 2.3 & 1.4 & -3.5 & -0.8 & -0.2 & -0.3 \\
\hline 3 Armenia & 3.5 & 1.1 & 2.4 & -0.1 & -1.9 & 4.4 & -1.1 & -2.9 & 0.6 \\
\hline 4 Bangladesh & -1.2 & -1.3 & 0.2 & 2.3 & -2.1 & 0.0 & 0.8 & 0.6 & -0.6 \\
\hline 5 Benin & 2.0 & -0.4 & 2.4 & -0.8 & 2.4 & 0.8 & -0.1 & -3.9 & -1.9 \\
\hline 6 Bhutan & -11.8 & -1.7 & -10.1 & 5.5 & -17.0 & 1.4 & 1.5 & 6.7 & -5.1 \\
\hline 7 Burkina Faso & -0.7 & -1.4 & 0.7 & 0.1 & 1.3 & -0.7 & -0.9 & -2.0 & -2.7 \\
\hline 8 Burundi & 0.4 & -2.0 & 2.4 & -0.4 & -1.9 & 4.8 & 9.4 & 1.5 & 1.9 \\
\hline 9 Cambodia & -0.7 & -1.4 & 0.7 & 5.8 & -8.8 & 3.6 & -1.5 & -0.6 & -1.4 \\
\hline 10 Cape Verde & 5.2 & 1.8 & 3.4 & 1.7 & -2.7 & 4.4 & 2.7 & -0.1 & 5.2 \\
\hline 11 Central African Rep. & 0.6 & -1.4 & 2.0 & 0.1 & 0.7 & 1.2 & 1.1 & 1.1 & 1.7 \\
\hline 12 Comoros & -0.1 & -0.5 & 0.4 & -3.4 & -0.2 & 4.1 & 3.1 & 0.7 & 0.7 \\
\hline 13 Côte d'Ivoire & -1.1 & -5.6 & 4.4 & 2.1 & 0.5 & 1.8 & 1.4 & 5.2 & 4.1 \\
\hline 14 Djibouti & -9.7 & -2.4 & -7.3 & -3.0 & -3.1 & -1.2 & -0.9 & 4.6 & -5.1 \\
\hline 15 Dominica & -13.3 & -2.3 & -11.0 & 3.6 & -3.1 & -11.6 & -0.8 & 13.9 & 0.6 \\
\hline 16 Eritrea & -5.2 & 6.4 & -11.7 & -3.0 & 27.1 & -35.8 & -45.4 & 8.3 & 3.1 \\
\hline 17 Ethiopia & -6.8 & -2.4 & -4.5 & 2.0 & -6.8 & 0.3 & 0.2 & 2.3 & -4.5 \\
\hline 18 Gambia, The & -8.0 & -5.3 & -2.7 & -0.4 & -3.6 & 1.3 & -2.3 & 11.2 & 3.2 \\
\hline 19 Georgia & -0.1 & 0.5 & -0.6 & -0.6 & -3.2 & 3.3 & -1.9 & -0.3 & -0.4 \\
\hline 20 Ghana & -8.3 & -2.7 & -5.6 & -8.6 & -2.1 & 5.0 & 2.1 & -0.5 & -8.8 \\
\hline 21 Grenada & -0.5 & -3.2 & 2.7 & -4.8 & -6.5 & 13.9 & 14.6 & 0.0 & -0.5 \\
\hline 22 Guinea & 0.0 & -1.8 & 1.8 & 5.1 & -3.1 & -0.2 & 0.1 & 2.7 & 2.7 \\
\hline 23 Guinea-Bissau & 1.3 & 0.8 & 0.5 & 10.8 & -6.4 & -3.8 & -1.5 & 45.9 & 47.1 \\
\hline 24 Guyana & -12.4 & -6.1 & -6.3 & 2.5 & -16.1 & 7.3 & 0.6 & 17.7 & 5.3 \\
\hline 25 Haiti & 0.6 & -2.9 & 3.4 & -2.0 & 3.8 & 1.6 & 1.0 & 0.1 & 0.6 \\
\hline 26 Honduras & 3.7 & -3.2 & 6.9 & 2.4 & -2.8 & 7.3 & 7.9 & 2.0 & 5.7 \\
\hline 27 India & -4.0 & -1.5 & -2.5 & 5.8 & -4.8 & -3.4 & -0.7 & 0.7 & -3.2 \\
\hline 28 Kenya & -7.4 & -1.0 & -6.4 & 1.0 & -5.6 & -1.8 & -1.4 & 6.2 & -1.2 \\
\hline 29 Kiribati & -27.6 & 0.0 & -27.6 & -4.4 & -41.6 & 18.4 & -13.8 & 11.7 & -15.9 \\
\hline 30 Kyrgyz Republic & -3.9 & -3.6 & -0.4 & -0.2 & -4.7 & 4.5 & 9.1 & 4.6 & 0.7 \\
\hline 31 Lao PDR & -8.3 & 0.0 & -8.3 & 2.3 & -9.3 & -1.3 & -0.6 & 5.1 & -3.2 \\
\hline 32 Lesotho & -4.0 & 0.0 & -4.0 & 3.5 & -16.7 & 9.3 & 7.4 & 1.4 & -2.5 \\
\hline \multicolumn{10}{|l|}{33 Liberia } \\
\hline 34 Madagascar & -7.9 & -1.8 & -6.1 & 4.7 & -7.2 & -3.7 & -0.5 & 7.6 & -0.3 \\
\hline 35 Malawi & -0.1 & -2.2 & 2.1 & -0.4 & -2.0 & 4.5 & 3.4 & 1.4 & 1.4 \\
\hline \multicolumn{10}{|l|}{36 Maldives } \\
\hline 37 Mali & -3.0 & -3.1 & 0.1 & -1.0 & 1.9 & -0.8 & -0.7 & 0.0 & -3.0 \\
\hline 38 Mauritania & -17.2 & 1.1 & -18.3 & 6.3 & -19.4 & -5.2 & -1.5 & 13.9 & -3.3 \\
\hline 39 Moldova & 1.3 & 0.3 & 1.0 & -4.6 & -3.9 & 9.5 & -1.6 & 0.8 & 2.1 \\
\hline 40 Mongolia & 12.2 & -4.6 & 16.8 & 12.6 & 5.7 & -1.4 & -0.9 & 2.1 & 14.3 \\
\hline $41 \mathrm{Moz}$ & 3.2 & -0.2 & 3.4 & 3.4 & 0.3 & -0.3 & 0.2 & -6.5 & -3.3 \\
\hline 42 Myanmar & 4.5 & 0.0 & 4.5 & 42.9 & -21.1 & -17.3 & 3.1 & -0.3 & 4.2 \\
\hline 43 Nepal & 2.9 & -0.8 & 3.7 & -1.1 & 3.3 & 1.6 & 1.5 & -4.9 & -2.0 \\
\hline 44 Nicaragua & 1.2 & -4.4 & 5.6 & 5.9 & -5.0 & 4.7 & 3.0 & -3.3 & -2.1 \\
\hline 45 Niger & -0.5 & -1.3 & 0.8 & 0.1 & -0.9 & 1.6 & 1.4 & 2.6 & 2.1 \\
\hline 46 Pakistan & -5.8 & -1.0 & -4.8 & 0.2 & -3.5 & -1.6 & 0.5 & 1.9 & -3.9 \\
\hline 47 Rwanda & 3.9 & 0.5 & 3.4 & 1.2 & -4.0 & 6.2 & 5.8 & 2.1 & 6.0 \\
\hline 48 Samoa & 8.3 & 1.7 & 6.6 & -1.5 & -10.8 & 18.9 & -1.7 & -6.7 & 1.6 \\
\hline 49 São Tomé and Príncipe & -10.8 & -6.2 & -4.5 & -4.5 & 3.1 & -3.2 & -8.5 & 37.0 & 26.3 \\
\hline 50 Senegal & -1.3 & -0.8 & -0.5 & -1.3 & 0.3 & 0.5 & -0.2 & -3.6 & -4.9 \\
\hline 51 Sierra Leone & -0.9 & -4.8 & 3.9 & 4.1 & 6.2 & -6.4 & -3.7 & 2.9 & 2.0 \\
\hline 52 Solomon Islands & -9.2 & -3.5 & -5.7 & 3.0 & -9.5 & 0.7 & -3.5 & 0.8 & -8.4 \\
\hline \multicolumn{10}{|l|}{53 Somalia } \\
\hline 54 Sri Lanka & -2.0 & -2.4 & 0.4 & -1.8 & 1.1 & 1.1 & 1.0 & 2.6 & 0.6 \\
\hline 55 St. Lucia & 3.6 & 1.3 & 2.3 & 1.0 & -6.3 & 7.6 & -1.0 & -8.4 & -4.8 \\
\hline 56 St. Vincent and the Grenadines & -7.7 & -1.5 & -6.2 & -1.9 & -3.6 & -0.8 & -0.3 & 9.6 & 1.9 \\
\hline 57 Tajikistan & -2.2 & -0.3 & -1.8 & -9.4 & 3.1 & 4.5 & 4.0 & 0.8 & -1.4 \\
\hline 58 Tanzania & -0.2 & -2.8 & 2.6 & 6.4 & -2.5 & -1.3 & 1.1 & -2.4 & -2.6 \\
\hline \multicolumn{10}{|l|}{59 Timor Leste } \\
\hline 60 Togo & -2.2 & -1.3 & -0.9 & -3.9 & 2.8 & 0.2 & 0.3 & 0.1 & -2.0 \\
\hline 61 Tonga & 0.8 & 1.0 & -0.2 & -6.0 & 0.4 & 5.3 & 1.3 & -0.7 & 0.1 \\
\hline 62 Uganda & 4.6 & 0.3 & 4.2 & 0.9 & -0.6 & 4.0 & 3.3 & -4.0 & 0.6 \\
\hline 63 Uzbekistan & 2.1 & 0.0 & 2.1 & 3.0 & -2.3 & 1.3 & -0.3 & -2.7 & -0.6 \\
\hline 64 Vanuatu & 3.1 & 1.3 & 1.8 & 3.0 & -9.4 & 8.3 & -1.6 & -3.4 & -0.3 \\
\hline 65 Zambia & 5.0 & -0.9 & 5.9 & 4.7 & 3.9 & -2.8 & 0.1 & -1.6 & 3.3 \\
\hline 66 Zimbabwe & -8.2 & -4.3 & -3.9 & 25.2 & -22.4 & -6.7 & 2.1 & 5.9 & -2.3 \\
\hline
\end{tabular}

Note: Country desk submissions as recorded by WEO on April 2006. $\mathrm{CA}=$ current account; $\mathrm{KA}=$ capital account; $\mathrm{BOP}=$ balance of payments. 
Table 2. Selected Economic Indicators for PRGF-Eligible Countries: 2003-05

\begin{tabular}{|c|c|c|c|c|c|c|c|c|c|}
\hline & $\begin{array}{l}\text { Real GDP Growth } \\
2003-05\end{array}$ & $\begin{array}{c}\text { Change in } \\
\text { Export Values }\end{array}$ & $\begin{array}{l}\mathrm{o} / \mathrm{w} \\
\text { Price }\end{array}$ & $\begin{array}{c}\mathrm{o} / \mathrm{w} \\
\text { Volume }\end{array}$ & $\begin{array}{c}\text { Change in } \\
\text { Non-oil imports }\end{array}$ & $\begin{array}{l}\mathrm{o} / \mathrm{w} \\
\text { Price }\end{array}$ & $\begin{array}{c}\mathrm{o} / \mathrm{w} \\
\text { Volume }\end{array}$ & $\begin{array}{c}\text { Imputed } \\
\text { Volume Change }\end{array}$ & $\begin{array}{l}\text { Terms } \\
\text { of Trade }\end{array}$ \\
\hline Average & 3.7 & 30.3 & 14.8 & 14.0 & 38.7 & 20.5 & 17.6 & -13.1 & -2.8 \\
\hline
\end{tabular}

IMPORTERS ONLY (66)

\begin{tabular}{|c|c|c|c|c|c|c|c|c|c|}
\hline 1 Afghanistan & 10.5 & & & & & & & 0.0 & 0.0 \\
\hline 2 Albania & 17.3 & 64.4 & 23.9 & 20.9 & 40.6 & 17.9 & 22.7 & -11.7 & 1.5 \\
\hline 3 Armenia & 12.4 & 36.1 & 15.8 & 21.1 & 43.8 & 19.4 & 24.4 & -41.5 & 1.5 \\
\hline 4 Bangladesh & 1.3 & 30.6 & 14.4 & 14.0 & 28.7 & 12.8 & 15.9 & 4.0 & -2.5 \\
\hline $5 \overline{\text { Benin }}$ & 8.8 & 17.2 & 18.2 & -3.7 & 6.0 & 13.6 & -7.6 & -22.9 & -2.2 \\
\hline 6 Bhutan & 12.2 & 68.8 & 51.8 & 8.7 & 118.4 & 111.3 & 7.1 & 9.2 & 0.0 \\
\hline 7 Burkina Faso & 12.5 & 36.0 & 51.9 & -9.5 & 20.5 & -3.2 & 23.7 & 4.7 & -14.4 \\
\hline 8 Burundi & 3.2 & 28.4 & -6.5 & 70.5 & 49.6 & 28.9 & 20.7 & 12.7 & 1.5 \\
\hline $9 \overline{\text { Cambodia }}$ & 6.2 & 37.0 & 30.0 & 2.9 & 46.9 & 15.8 & 31.1 & -22.8 & 1.5 \\
\hline 10 Cape Verde & 11.2 & 28.8 & 19.6 & 13.8 & 31.0 & 27.9 & 3.1 & -55.9 & 2.1 \\
\hline 11 Central African Rep. & 7.2 & 16.2 & -1.7 & 3.5 & 6.1 & -3.6 & 9.7 & 43.5 & -4.1 \\
\hline 12 Comoros & 4.8 & -5.2 & -31.9 & -34.0 & 18.9 & 15.8 & 3.1 & -30.0 & -19.5 \\
\hline $13 \overline{\text { Côte d'Ivoire }}$ & 6.3 & 23.1 & 13.7 & 8.8 & 14.2 & 1.5 & 12.7 & 44.5 & -4.8 \\
\hline 14 Djibouti & 3.1 & 4.3 & -15.5 & 14.5 & 23.7 & -2.0 & 25.7 & -13.6 & -3.1 \\
\hline 15 Dominica & 3.0 & 18.2 & 5.2 & 3.1 & 18.5 & 8.1 & 10.4 & -15.0 & -0.5 \\
\hline 16 Eritrea & 12.2 & 14.7 & 13.7 & 15.1 & -2.7 & -24.6 & 21.8 & -42.7 & -13.1 \\
\hline $17 \overline{\text { Ethiopia }}$ & 10.6 & 60.5 & 42.0 & 19.3 & 89.0 & 69.7 & 19.3 & 25.9 & -0.6 \\
\hline 18 Gambia, The & 4.6 & 29.0 & 55.9 & -22.7 & 41.4 & 38.2 & 3.2 & 53.0 & -2.0 \\
\hline 19 Georgia & 17.8 & 57.4 & 92.0 & 0.0 & 77.2 & 76.9 & 0.3 & -36.7 & -0.3 \\
\hline 20 Ghana & 3.6 & 10.8 & 17.6 & -7.1 & 48.5 & 10.0 & 38.5 & 3.6 & -14.8 \\
\hline 21 Grenada & -0.8 & -5.8 & -43.1 & 23.8 & 21.6 & 2.3 & 19.3 & 1.6 & -7.2 \\
\hline 22 Guinea & -21.2 & 11.7 & 9.3 & 2.3 & 11.8 & -10.5 & 22.3 & -19.1 & -7.6 \\
\hline 23 Guinea-Bissau & 7.4 & 65.6 & 22.7 & 31.6 & 51.6 & 32.2 & 19.5 & -47.8 & 5.0 \\
\hline 24 Guyana & -2.8 & 7.8 & -13.0 & 24.6 & 34.6 & 1.2 & 33.4 & -25.6 & -6.0 \\
\hline $25 \overline{\text { Haiti }}$ & 0.7 & 24.1 & $\begin{array}{c}-0.9 \\
\end{array}$ & 26.1 & 25.8 & 17.3 & 8.5 & 21.8 & 3.7 \\
\hline 26 Honduras & 0.3 & 27.8 & 4.7 & 22.2 & 29.5 & 18.4 & 11.1 & -1.9 & -2.3 \\
\hline 27 India & 11.8 & 87.5 & 24.2 & 23.6 & 101.3 & 67.3 & 34.0 & 5.1 & -2.8 \\
\hline 28 Kenya & 4.9 & 32.8 & 13.3 & 12.4 & 67.6 & 38.6 & 29.0 & -18.9 & -5.4 \\
\hline $29 \overline{\text { Kiribati }}$ & -1.1 & -29.4 & -39.8 & 20.2 & 45.0 & 7.4 & 37.6 & -45.8 & -27.5 \\
\hline 30 Kyrgyz Republic & 6.6 & 26.4 & 0.4 & 15.8 & 45.8 & -2.3 & 48.1 & 8.9 & -11.0 \\
\hline 31 Lao PDR & 4.4 & 38.3 & 22.7 & 19.4 & 71.2 & 19.2 & 52.0 & -30.9 & -11.2 \\
\hline 32 Lesotho & 3.5 & 18.1 & 21.3 & -3.0 & 30.7 & 22.5 & 8.3 & -45.2 & -4.6 \\
\hline \multicolumn{10}{|l|}{$33 \overline{\text { Liberia }}$} \\
\hline 34 Madagascar & -18.3 & 3.9 & 14.1 & -23.3 & 23.4 & -0.1 & 23.5 & -33.2 & -21.2 \\
\hline 35 Malawi & -6.0 & 15.6 & 18.5 & -1.5 & 23.2 & 15.6 & 7.6 & -5.5 & -6.3 \\
\hline \multicolumn{10}{|l|}{36 Maldives } \\
\hline 37 Mali & 9.6 & 14.4 & 1.3 & 11.3 & 6.2 & 0.0 & 6.2 & 3.2 & -6.2 \\
\hline 38 Mauritania & 5.9 & 81.2 & 23.4 & 61.6 & 129.1 & 105.9 & 23.2 & -30.9 & 10.9 \\
\hline 39 Moldova & 12.3 & 37.3 & 26.4 & 7.7 & 59.4 & 24.3 & 35.1 & -21.9 & -7.2 \\
\hline 40 Mongolia & 6.0 & 76.0 & 19.6 & 40.7 & 28.7 & 12.2 & 16.5 & 13.6 & 11.9 \\
\hline $41 \overline{\mathrm{Moz}}$ & 9.0 & 54.7 & 12.7 & 49.3 & 36.5 & 16.6 & 19.9 & -19.8 & 11.6 \\
\hline 42 Myanmar & -24.4 & 31.1 & 0.5 & 34.9 & 13.6 & 1.2 & 12.4 & -45.8 & 12.7 \\
\hline 43 Nepal & 8.4 & 19.3 & 25.9 & 0.6 & 9.3 & 22.0 & -12.7 & -17.1 & 0.0 \\
\hline 44 Nicaragua & -0.6 & 43.3 & 47.0 & 0.0 & 35.6 & 52.1 & -16.4 & 1.6 & -1.5 \\
\hline 45 Niger & 8.9 & 28.7 & 20.4 & 7.9 & 35.6 & 6.8 & 28.8 & 4.1 & -17.7 \\
\hline 46 Pakistan & 5.5 & 33.5 & 19.0 & 15.8 & 75.7 & 63.0 & 12.7 & -8.6 & -6.2 \\
\hline 47 Rwanda & 2.8 & 44.5 & 13.3 & 41.1 & 70.3 & 18.2 & 52.2 & -42.4 & -2.4 \\
\hline 48 Samoa & 4.3 & 12.5 & 32.6 & -31.6 & 53.0 & 10.0 & 43.1 & -50.8 & 2.2 \\
\hline $49 \overline{\text { São Tomé and Príncipe }}$ & -2.8 & 3.7 & 30.0 & -26.3 & 11.3 & 13.6 & -2.3 & 15.1 & -3.0 \\
\hline 50 Senegal & 12.1 & 24.0 & 6.3 & 18.3 & 28.3 & 14.5 & 13.8 & -19.2 & -2.1 \\
\hline 51 Sierra Leone & -4.2 & 45.3 & 10.6 & 30.2 & -11.8 & -17.4 & 5.6 & 11.8 & 0.5 \\
\hline 52 Solomon Islands & 4.6 & 35.4 & 33.8 & 1.3 & 63.5 & 33.8 & 29.7 & 14.6 & 1.8 \\
\hline \multicolumn{10}{|l|}{$53 \overline{\text { Somalia }}$} \\
\hline 54 Sri Lanka & 3.6 & 22.3 & 18.0 & 4.8 & 24.2 & 14.7 & 9.5 & 7.0 & -5.1 \\
\hline 55 St. Lucia & 4.7 & 17.4 & -5.3 & 53.0 & 32.6 & 16.9 & 15.7 & -48.9 & 2.3 \\
\hline 56 St. Vincent and the Grenadines & 4.7 & 9.0 & -2.8 & 12.0 & 23.2 & 8.3 & 14.9 & -21.1 & -3.3 \\
\hline 57 Tajikistan & 7.9 & 26.5 & 23.0 & -0.1 & 40.8 & 41.1 & -0.3 & -14.3 & -2.9 \\
\hline 58 Tanzania & 2.6 & 63.8 & 20.8 & 31.7 & 40.2 & 15.1 & 25.1 & 35.1 & 2.0 \\
\hline \multicolumn{10}{|l|}{59 Timor Leste } \\
\hline 60 Togo & 7.1 & 10.3 & -12.1 & 16.3 & 11.7 & -10.1 & 21.8 & -26.2 & -6.8 \\
\hline $61 \overline{\text { Tonga }}$ & 6.1 & 1.4 & 0.0 & 0.0 & 30.6 & 0.0 & 0.0 & -45.8 & 0.0 \\
\hline 62 Uganda & 10.4 & 50.0 & 16.8 & 32.6 & 45.2 & 19.0 & 26.1 & -36.5 & 6.8 \\
\hline 63 Uzbekistan & -1.3 & 40.7 & 34.2 & 8.0 & 42.7 & 37.1 & 5.6 & -45.8 & -0.4 \\
\hline 64 Vanuatu & 8.8 & 28.4 & 16.0 & 24.4 & 63.8 & 61.3 & 2.5 & -49.9 & -1.5 \\
\hline $65 \overline{\text { Zambia }}$ & 6.9 & 90.4 & 23.0 & 59.9 & 40.7 & 15.1 & 25.6 & 8.4 & 11.5 \\
\hline 66 Zimbabwe & -48.6 & 3.6 & -19.0 & 17.0 & 15.5 & -6.3 & 21.8 & -50.5 & -5.2 \\
\hline
\end{tabular}

Note: Country desk submissions as recorded by WEO on April 2006. 
Table 3. Domestic Retail Fuel Prices by Country

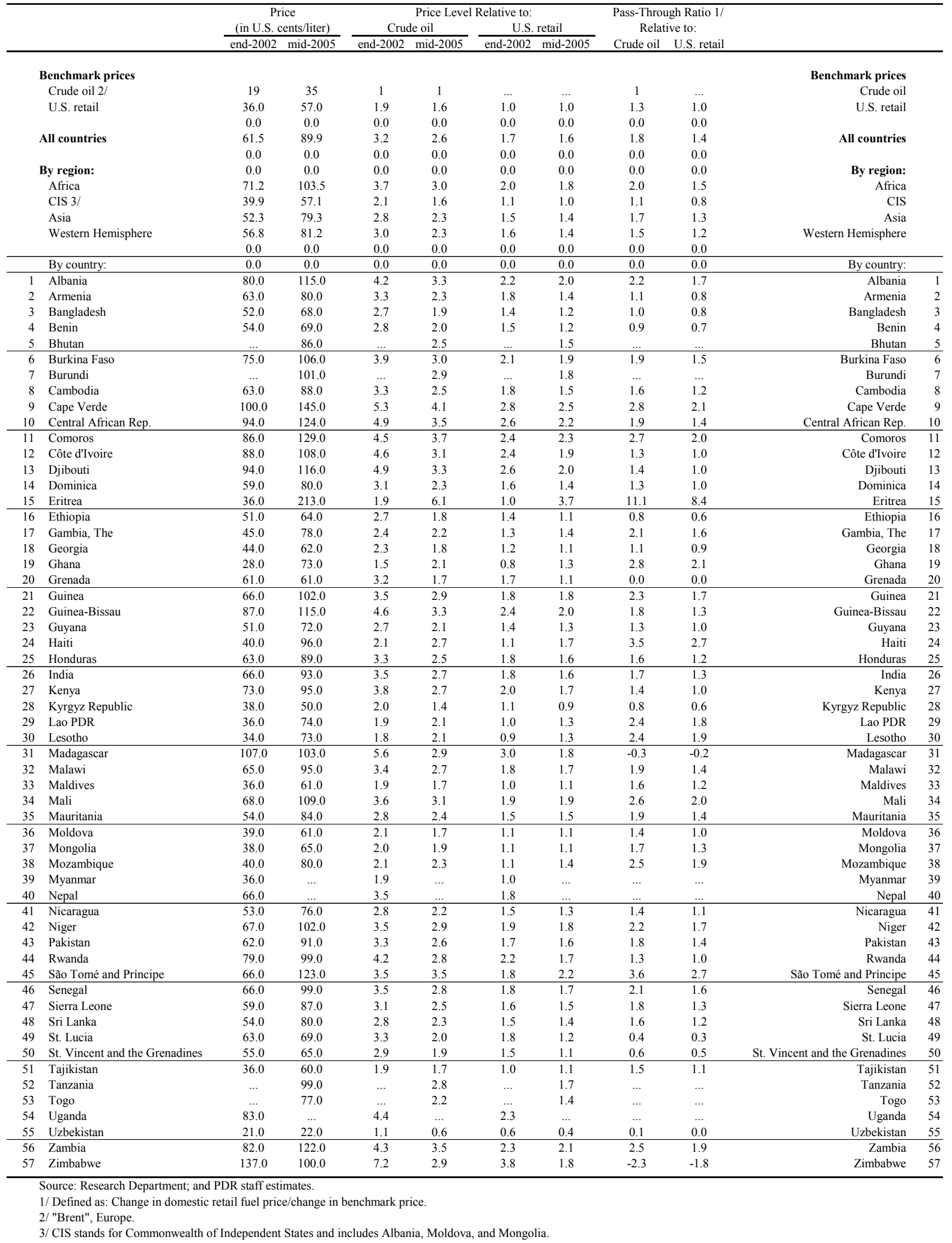


Table 4. Fiscal Developments by Country (Annual average change in 2003-05, in percent of GDP)

\begin{tabular}{|c|c|c|c|c|c|c|c|}
\hline & \multicolumn{7}{|c|}{ Memorandum Items: } \\
\hline & Overall balance & Expenditures 1/ & Revenues & Fuel taxation 2/ & Pass-through ratio $3 /$ & & \\
\hline All countries & 0.7 & -0.4 & 1.0 & $\ldots$ & 1.4 & All countries & \\
\hline By region: & & & & & & By region: & \\
\hline Africa 4/ & 1.3 & -0.3 & 1.6 & $\ldots$ & 1.5 & Africa & \\
\hline CIS & 0.5 & 0.6 & -0.1 & $\ldots$ & 0.8 & CIS & \\
\hline Asia & -0.5 & -0.6 & 0.1 & $\ldots$ & 1.3 & Asia & \\
\hline Western Hemisphere & 0.5 & -0.2 & 0.7 & $\cdots$ & 1.2 & Western Hemisphere & \\
\hline By fuel price policy: & & & & & & By fuel price policy: & \\
\hline "Pass through" countries & 0.8 & -0.3 & 1.1 & $\ldots$ & $\ldots$ & "Pass through" countries & \\
\hline "No pass through" countries 4 / & 0.2 & 0.5 & -0.3 & $\ldots$ & $\ldots$ & "No pass through" countries & \\
\hline By country: & & & & & & By country: & \\
\hline 1 Albania & 0.9 & 0.9 & 0.0 & ++ & 1.7 & Albania & 1 \\
\hline 2 Armenia & -0.7 & 1.2 & -1.9 & - & 0.8 & Armenia & 2 \\
\hline 3 Bangladesh & $\ldots$ & $\ldots$ & $\ldots$ & - & 0.8 & Bangladesh & 3 \\
\hline 4 Benin & 0.0 & -0.4 & 0.5 & + & 0.7 & Benin & 4 \\
\hline 5 Bhutan & -2.6 & -1.3 & -1.3 & + & $\ldots .$. & Bhutan & 5 \\
\hline 6 Burkina Faso & 0.3 & 0.3 & 0.0 & "'m+' & 1.5 & Burkina Faso & 6 \\
\hline 7 Burundi & -1.9 & -4.6 & 2.7 & + & $\ldots$. & Burundi & 7 \\
\hline 8 Cambodia & 1.2 & 1.0 & 0.2 & + & 1.2 & Cambodia & 8 \\
\hline 9 Cape Verde & -0.1 & -0.3 & 0.3 & ++ & 2.1 & Cape Verde & 9 \\
\hline 10 Central African Rep. & -0.6 & 1.0 & -1.5 & ++ & 1.4 & Central African Rep. 1 & 10 \\
\hline 11 Comoros & 1.7 & 2.4 & -0.7 & $\ldots$ & 2.0 & Comoros 1 & 11 \\
\hline 12 Côte d'Ivoire & -0.2 & -0.2 & 0.0 & + & 1.0 & Côte d'Ivoire 1 & 12 \\
\hline 13 Djibouti & 1.3 & -1.3 & 2.7 & + & 1.0 & Djibouti 1 & 13 \\
\hline 14 Dominica & 1.8 & 0.1 & 1.7 & + & 1.0 & Dominica 1 & 14 \\
\hline 15 Eritrea & 4.2 & 4.6 & -0.4 & + & 8.4 & Eritrea 1 & 15 \\
\hline 16 Ethiopia & 0.9 & 0.8 & 0.1 & + & 0.6 & Ethiopia 1 & 16 \\
\hline 17 Gambia, The & -0.5 & -0.9 & 0.4 & + & 1.6 & Gambia, The 1 & 17 \\
\hline 18 Georgia & 0.2 & 0.0 & 0.1 & - & 0.9 & Georgia 1 & 18 \\
\hline 19 Ghana & $\ldots$ & $\ldots$ & $\ldots$ & - & 2.1 & Ghana 1 & 19 \\
\hline 20 Grenada & $\ldots$ & $\ldots$ & $\ldots$ & + & 0.0 & Grenada 2 & 20 \\
\hline 21 Guinea & 1.2 & 1.3 & -0.1 & + & 1.7 & Guinea 2 & 21 \\
\hline 22 Guinea-Bissau & 1.0 & -1.2 & 2.2 & + & 1.3 & Guinea-Bissau 2 & 22 \\
\hline 23 Guyana & -2.5 & -4.8 & 2.3 & + & 1.0 & Guyana 2 & 23 \\
\hline 24 Haiti & 0.8 & -0.9 & 1.7 & $\ldots$ & 2.7 & Haiti 2 & 24 \\
\hline 25 Honduras & 1.9 & 2.0 & 0.0 & + & 1.2 & Honduras 2 & 25 \\
\hline 26 India & 0.8 & 0.2 & 0.6 & + & 1.3 & India 2 & 26 \\
\hline 27 Kenya & 0.7 & 0.8 & -0.1 & + & 1.0 & Kenya 2 & 27 \\
\hline 28 Kiribati & -6.0 & -3.8 & -2.2 & $\ldots$ & $\ldots$. & Kiribati 2 & 28 \\
\hline 29 Kyrgyz Republic & 0.5 & 0.0 & 0.5 & - & 0.6 & Kyrgyz Republic 2 & 29 \\
\hline 30 Lao PDR & -0.1 & 0.3 & -0.4 & + & 1.8 & Lao PDR 3 & 30 \\
\hline 31 Lesotho & 2.1 & -2.3 & 4.5 & + & 1.9 & Lesotho 3 & 31 \\
\hline 32 Madagascar & 0.0 & -2.0 & 2.0 & + & -0.2 & Madagascar 3 & 32 \\
\hline 33 Malawi & 2.1 & -3.8 & 5.9 & + & 1.4 & Malawi 3 & 33 \\
\hline 34 Maldives & -2.5 & -6.3 & 3.8 & $\ldots$ & 1.2 & Maldives 3 & 34 \\
\hline 35 Mali & -0.2 & -1.0 & 0.9 & + & 2.0 & Mali 3 & 35 \\
\hline 36 Mauritania & -2.7 & 0.7 & -3.4 & + & 1.4 & Mauritania 3 & 36 \\
\hline 37 Moldova & 0.5 & -1.1 & 1.6 & $\ldots$ & 1.0 & Moldova 3 & 37 \\
\hline 38 Mongolia & 2.1 & 2.6 & -0.6 & + & 1.3 & Mongolia 3 & 38 \\
\hline 39 Mozambique & 0.5 & 1.0 & -0.5 & + & 1.9 & Mozambique 3 & 39 \\
\hline 40 Myanmar & -0.8 & -2.4 & 1.6 & -- & $\ldots$ & Myanmar 4 & 40 \\
\hline 41 Nepal & 1.0 & -0.4 & 1.5 & +"'s+' & (n) & Nepal 4 & 41 \\
\hline 42 Nicaragua & 2.0 & 0.5 & 1.5 & ++ & 1.1 & Nicaragua 4 & 42 \\
\hline 43 Niger & -0.4 & -0.3 & -0.1 & + & 1.7 & Niger 4 & 43 \\
\hline 44 Pakistan & -0.3 & 0.5 & -0.9 & + & 1.4 & Pakistan 4 & 44 \\
\hline 45 Rwanda & & & $\ldots$ & + & 1.0 & Rwanda 4 & 45 \\
\hline 46 Samoa & 0.8 & 0.8 & 0.0 & $\cdots$ & $\ldots$ & Samoa 4 & 46 \\
\hline 47 São Tomé and Príncipe & 24.5 & -2.0 & 26.4 & $\ldots$ & 2.7 & São Tomé and Príncipe 4 & 47 \\
\hline 48 Senegal & -0.9 & -1.3 & 0.3 & + & 1.6 & Senegal 4 & 48 \\
\hline 49 Sierra Leone & 2.1 & 2.3 & -0.2 & ++ & 1.3 & Sierra Leone 4 & 49 \\
\hline 50 Solomon Islands & 2. & . & - & ? & . & Solomon Islands 5 & 50 \\
\hline 51 Sri Lanka & 0.4 & 0.5 & -0.1 & + & 1.2 & Sri Lanka 5 & 51 \\
\hline 52 St. Lucia & 0.5 & 2.5 & -2.0 & $\ldots$ & 0.3 & St. Lucia 5 & 52 \\
\hline 53 St. Vincent and the Grenadines & -0.7 & -0.6 & -0.1 & $\cdots$ & 0.5 & St. Vincent and the Grenadines 5 & 53 \\
\hline 54 Tajikistan & -0.3 & -1.4 & 1.1 & + & 1.1 & Tajikistan 5 & 54 \\
\hline 55 Tanzania & -0.8 & -2.5 & 1.8 & + & $\ldots$ & Tanzania 5 & 55 \\
\hline 56 Togo & -0.1 & -1.0 & 0.9 & + & ...' & Togo 5 & 56 \\
\hline 57 Tonga & 0.2 & 2.1 & -1.9 & $\ldots$ & $\ldots$ & Tonga 5 & 57 \\
\hline 58 Uganda & 1.7 & $\begin{array}{l}2.1 \\
1.0\end{array}$ & 0.7 & $\begin{array}{l}* \\
+\end{array}$ & $\begin{array}{l}\cdots \\
\ldots\end{array}$ & Uganda 5 & 58 \\
\hline 59 Uzbekistan & 1.0 & 2.5 & -1.5 & - & 0.0 & Uzbekistan 5 & 59 \\
\hline 60 Vanuatu & 1.7 & 1.4 & 0.3 & $\ldots$ & $\ldots$ & Vanuatu 6 & 60 \\
\hline 61 Zambia & 0.9 & 1.9 & -1.0 & + & 1.9 & Zambia 6 & 61 \\
\hline 62 Zimbabwe & -1.1 & -9.9 & 8.8 & + & -1.8 & Zimbabwe 6 & 62 \\
\hline
\end{tabular}

Source: WEO; Research Department; www.internationalfuelprices.com; and PDR staff estimates.

1/ A minus indicates an increase in expenditures.

2/ Fuel tax dependence can be high (++) or normal (+). Fuel price subsidization can be low (-) or high (--) 


\section{APPENDIX I-COMPARISON TO OIL SHOCKS OF THE 1970S}

Unlike the most recent rise in oil prices, the sharp spikes of the 1970s contributed to a worsening of the balance of payments positions of low-income countries. Charts 1 and 2 below show the balance of payments developments for 40 to 45 low-income countries for the two-year periods $1973-75$ and $1978-80$ when oil prices rose dramatically. ${ }^{21}$

Although roughly similar in magnitude to the current shock (around 1 1/2 percent of GDP on average), the oil price increases of the 1970s were not fully offset by higher exports. This, combined with increases in non-oil imports, led to much larger current account deficits. Again, unlike the current period, these current account deficits were only partly offset by larger capital account surpluses, resulting in deteriorations in the overall balance of payments positions of $0.7-0.8$ percent of GDP. Moreover, data suggest that the capital account surpluses of the earlier periods were due to higher borrowing, with net indebtedness picking up considerably in many countries.

Oil Shock and BOP Impact

(In percent of GDP)
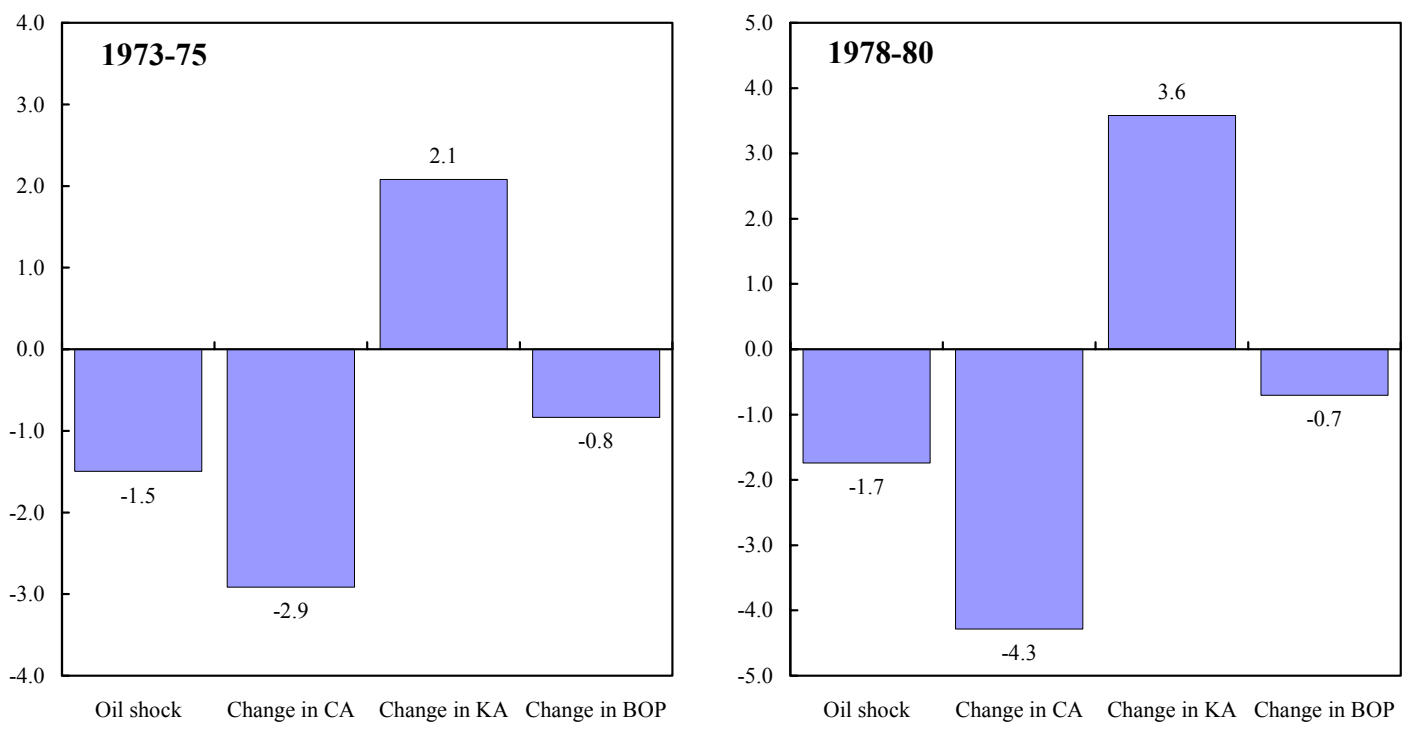

Note: $\mathrm{CA}=$ current account; $\mathrm{KA}=$ capital account; $\mathrm{BOP}=$ balance of payments.

\footnotetext{
${ }^{21}$ The countries covered (42 for 1973-75 and 45 for 1978-80) represent current PRGF-eligible oil importers for which sufficient WEO data was available, excluding countries with changes in oil imports of greater than two standard deviations.
} 


\section{APPENDIX II-ECONOMETRIC ANALYSIS}

First, the response of oil import volumes to changes in the oil price, income, and external factors was studied. Specifically, a panel of oil importers was used to estimate the elasticity of oil import volumes to the oil price, real GDP, and the non-oil terms of trade for three different time periods: 1965-2000, 1980-99, and 2000-05. These periods were chosen to study elasticity under three different environments. While the 1965-2000 period is suitable to explain long-run elasticity, the 1980-99 and 2000-05 periods are substantially different: in the former, oil prices oscillated nominally but declined in real terms; in the latter, prices followed an opposite pattern, with steady nominal and real increases.

For the regressions, oil import volumes (in barrels) were used as the dependent variables, and the international average oil price, a one-year lag of real GDP, and the non-oil terms of trade were used as explanatory variables. All variables were expressed in their natural logarithm and a random effect estimation was run.

The main finding is that the estimated price elasticity has been almost the same for the longrun, 1965-2000, and for the most recent period, 2000-05. However, price elasticity for the 1980-99 period is almost double that of the other two periods (see Table A.1). This seems to indicate that in periods when oil prices decrease in real terms and are expected to keep decreasing, oil imports rise more rapidly than they fall when prices are expected to increase. Income elasticity instead demonstrates the opposite pattern. It is much higher in 2000-05 and in 1965-2000 than it is in 1980-99.

Turning the focus to 2003-05, the period emphasized in the paper, a cross-country analysis was conducted for the relationship between oil imports and variables intended to capture a country's changes in income, the degree of price pass-through, the improvement or deterioration in the external environment, and a country's need for oil.

In the set of regression presented in Table A.2, the percentage change in oil import volumes between 2003 and 2005 is the dependent variable. The increase in income was proxied by the growth rate of real GDP or the growth rate in export volumes. ${ }^{22}$ The degree of pass-through of oil prices was measured as the change in the domestic retail fuel prices over the change in the US domestic retail price. Changes in the external environment were proxied by the percentage change in the terms of trade and, in one specification, by the non-oil terms of trade. ${ }^{23}$ Oil intensity in 2002 was measured as the ratio of volume of oil imported in 2002 over real GDP (i.e., barrels per unit of real output, where real output is measured in thousands of U.S. dollars at 2002 prices). In some specifications for 2002, real GDP was

\footnotetext{
${ }^{22}$ As the change in population is minimal between 2003 and 2005, this would be the same as using per capita GDP.

${ }^{23} \mathrm{We}$ measured the non-oil terms of trade as the ratio of the export price index over the non-oil imports price index.
} 
used instead. ${ }^{24}$ Finally, because the international average for the price of oil was used across the study, the change in oil price between 2003 and 2005 could not be used as an explanatory variable, as this would be equal for all countries and hence captured within the constant.

OLS analysis was conducted for the set of oil importers. Although the proposed specifications do not tackle the problem of endogeneity, this analysis was inconclusive as far as strong relationships between changes in oil import volumes and the proposed explanatory variables (see Table A.2). Other specifications were also tried, for instance using a lag of the growth rate as an instrument for growth, but no evidence of strong relationships was found.

As a next step, the sharp change in oil import volumes was investigated to see if it had an effect on growth between 2003 and 2005. First, simple regressions were carried out with growth between 2003 and 2005 as the dependent variable and the change in oil import volumes as the explanatory variable. Some variables that are standard in growth analysis were controlled for (for instance, investment, public spending on education, life expectancy, terms of trade shocks), but no evidence emerged that the recent adjustments in oil import volumes slowed growth between 2003 and 2005. Additional analysis was also performed. First, a growth accounting exercise was conducted for each country in the sample, covering the period 1975-2002 (or the earliest period after 1975 for which data was available). Population was used as a proxy for the labor force and capital was constructed with the perpetual inventory model. The estimated coefficients were then used to predict growth in the period 2003-05. For the prediction, both the actual values of capital and population and the 2000-02 average were used. The discrepancy between actual and predicted growth was then computed and regressed against changes in oil import volumes and changes in the non-oil terms of trade. No evidence was found of a relationship between oil volume adjustments and a shortfall in growth with respect to the predicted rates.

Finally, OLS analysis was used to study the relationship between borrowing, oil imports, transfers, the non-oil current account balance, and the terms of trade. Specifically, the change in borrowing as a percentage of GDP between 2003 and 2005 was used as the dependent variable. The explanatory variables were the change in the level of oil import volumes over real GDP (i.e., barrels per unit of output), the change in the terms of trade, the change in the non-oil current account as a percentage of GDP, and the change in grants as a percentage of GDP. This was done for the entire group of oil importers (see Table A.3). The only estimates that are statistically significant are those for the change in oil imports and the non-oil current account. This result suggests that countries that experienced a larger drop in the non-oil current account were also countries that resorted to borrowing.

\footnotetext{
${ }^{24}$ We also used real GDP per capita in 2002 instead of real GDP, and the results did not change.
} 
Table A.1. Regression for Elasticity

\begin{tabular}{|c|c|c|c|}
\hline & $1965-2000$ & $1980-1999$ & $2000-2005$ \\
\hline \multirow[t]{3}{*}{ Constant } & -4.681 & -3.696 & -5.196 \\
\hline & $(.171)$ & $(.218)$ & $(.436)$ \\
\hline & -27.43 & -16.94 & -11.91 \\
\hline \multirow[t]{3}{*}{ Percent change in oil price } & -0.334 & -0.605 & -0.381 \\
\hline & $(.018)$ & $(.044)$ & $(.036)$ \\
\hline & -18.59 & -13.66 & -10.66 \\
\hline \multirow[t]{3}{*}{ Percent growth of real GDP (one-year lag) } & 0.818 & 0.669 & 0.910 \\
\hline & $(.034)$ & $(.041)$ & $(.045)$ \\
\hline & 23.75 & 16.41 & 20.46 \\
\hline \multirow[t]{3}{*}{ Percent change in non-oil terms of trade } & -0.133 & -0.151 & 0.035 \\
\hline & $(.031)$ & $(.04)$ & $(.088)$ \\
\hline & -4.27 & -3.80 & 0.40 \\
\hline No. Observation & 1,369 & 956 & 399 \\
\hline No. Groups & 58 & 58 & 58 \\
\hline R-squared within & 0.275 & 0.373 & 0.134 \\
\hline R-squared between & 0.792 & 0.794 & 0.881 \\
\hline R-squared overall & 0.788 & 0.827 & 0.866 \\
\hline
\end{tabular}

Note: coefficient in bold, standard errors between parenthesis, and t-statistics in italics. 
Table A.2. Regression for Oil Volumes

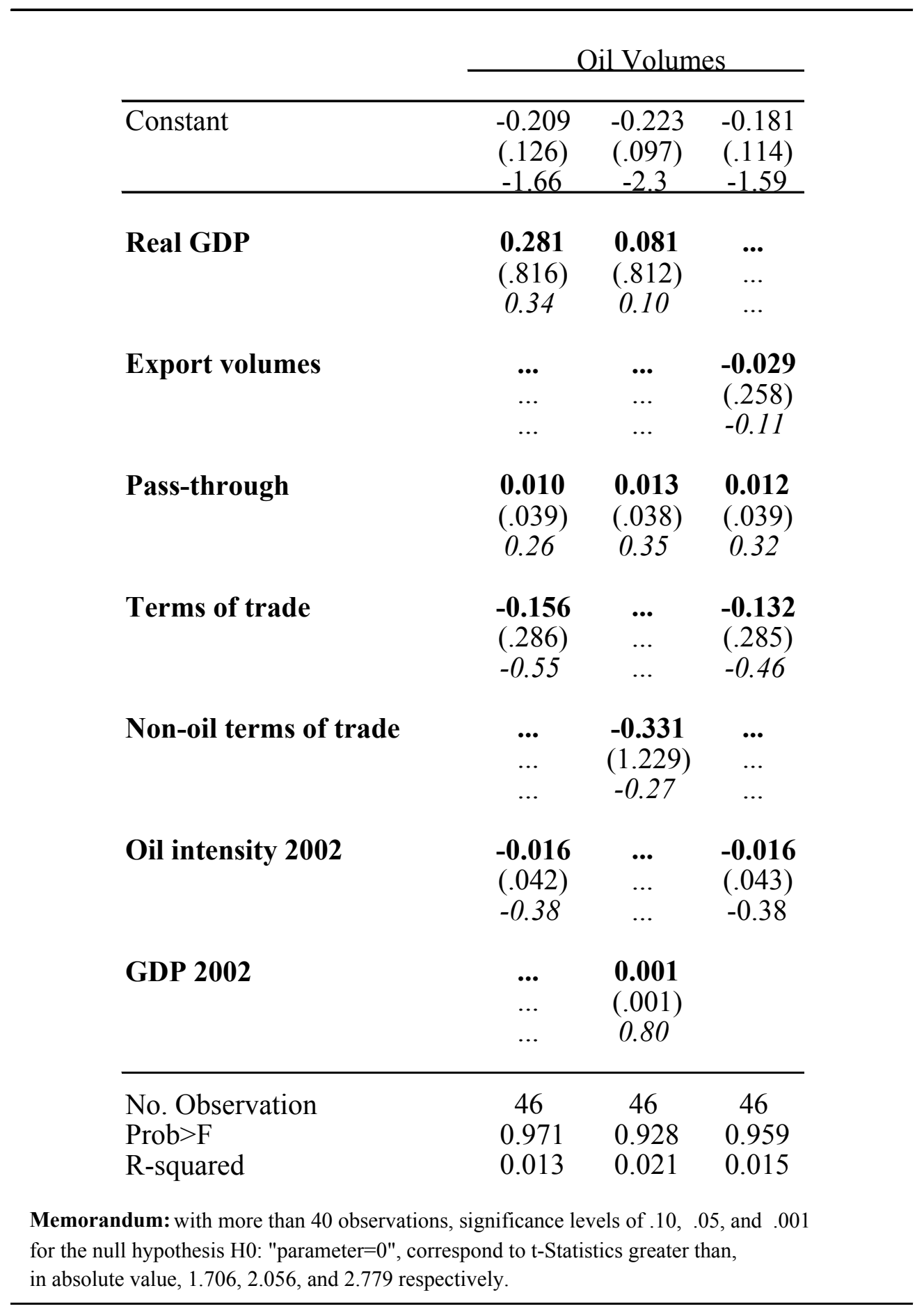

Note: coefficient in bold, standard errors between parenthesis, and t-statistics in italics. 
Table A.3. Regression for borrowing

\begin{tabular}{lc}
\hline & Borrowing (in percent of GDP) \\
\cline { 2 - 2 } Constant & 0.018 \\
& $(.011)$ \\
& 1.60 \\
\hline Barrels per unit of output & $\mathbf{0 . 0 4 6}$ \\
& $(.012)$ \\
& 3.69 \\
Grants (in percent of GDP) & $\mathbf{- 0 . 3 8 4}$ \\
& $(.253)$ \\
& -1.52 \\
Changes in non-oil current account & $\mathbf{- 0 . 5 7 6}$ \\
& $(.119)$ \\
Changes in terms of trade & -4.82 \\
& \\
R-squared & $\mathbf{0 . 0 0 0}$ \\
Memorandum: with more than 40 observations, significance levels of .10 & $(.001)$ \\
for the null hypothesis H0: "parameter $=0$ ", correspond to t-Statistics greater than & .05, and .001 \\
\hline No. Observation & 0.88 \\
\hline
\end{tabular}

Note: coefficient in bold, standard errors between parenthesis 